\title{
Cholesterol-Rich Lipid Rafts as Platforms for SARS-CoV-2 Entry
}

\author{
Selvin Noé Palacios-Rápalo ${ }^{1}$, Luis Adrián De Jesús-González ${ }^{1}$, \\ Carlos Daniel Cordero-Rivera ${ }^{1}$, Carlos Noe Farfan-Morales ${ }^{1}$, Juan Fidel Osuna-Ramos ${ }^{1}$, \\ Gustavo Martínez-Mier ${ }^{2}$, Judith Quistián-Galván ${ }^{2}$, Armando Muñoz-Pérez ${ }^{2}$, \\ Víctor Bernal-Dolores ${ }^{2}$, Rosa María del Ángel ${ }^{1 *}$ and José Manuel Reyes-Ruiz ${ }^{2 *}$ \\ ${ }^{1}$ Department of Infectomics and Molecular Pathogenesis, Center for Research and Advanced Studies (CINVESTAV-IPN), \\ Mexico City, Mexico, ${ }^{2}$ Unidad Médica de Alta Especialidad, Hospital de Especialidades No. 14, Centro Médico Nacional \\ "Adolfo Ruiz Cortines", Instituto Mexicano del Seguro Social (IMSS) Veracruz Norte, Veracruz, Mexico
}

\section{OPEN ACCESS}

Edited by:

Kazuhisa Iwabuchi, Juntendo University, Japan

Reviewed by:

Shetty Ravi Dyavar, University of Nebraska Medical Center, United States

Nicholas Lennemann, University of Alabama at Birmingham, United States

*Correspondence: José Manuel Reyes-Ruiz jose.reyesr@imss.gob.mx

Rosa María del Ángel rmange/@cinvestav.mx

Specialty section: This article was submitted to Viral Immunology, a section of the journal

Frontiers in Immunology

Received: 18 October 2021 Accepted: 29 November 2021 Published: 16 December 2021

Citation: Palacios-Rápalo SN, De Jesús-González LA, Cordero-Rivera $C D$,

Farfan-Morales CN, Osuna-Ramos JF, Martínez-Mier G, Quistián-Galván J, Muñoz-Pérez A, Bernal-Dolores V, del Ángel RM and Reyes-Ruiz JM (2021) Cholesterol-Rich Lipid Rafts as Platforms for SARS-CoV-2 Entry.

Front. Immunol. 12:796855. doi: 10.3389/fimmu.2021.796855
Since its appearance, the Severe Acute Respiratory Syndrome Coronavirus (SARS-CoV2), the causal agent of Coronavirus Disease 2019 (COVID-19), represents a global problem for human health that involves the host lipid homeostasis. Regarding, lipid rafts are functional membrane microdomains with highly and tightly packed lipid molecules. These regions enriched in sphingolipids and cholesterol recruit and concentrate several receptors and molecules involved in pathogen recognition and cellular signaling. Cholesterol-rich lipid rafts have multiple functions for viral replication; however, their role in SARS-CoV-2 infection remains unclear. In this review, we discussed the novel evidence on the cholesterol-rich lipid rafts as a platform for SARS-CoV-2 entry, where receptors such as the angiotensin-converting enzyme-2 (ACE-2), heparan sulfate proteoglycans (HSPGs), human Toll-like receptors (TLRs), transmembrane serine proteases (TMPRSS), CD-147 and HDL-scavenger receptor B type 1 (SR-B1) are recruited for their interaction with the viral spike protein. FDA-approved drugs such as statins, metformin, hydroxychloroquine, and cyclodextrins (methyl- $\beta$-cyclodextrin) can disrupt cholesterolrich lipid rafts to regulate key molecules in the immune signaling pathways triggered by SARS-CoV-2 infection. Taken together, better knowledge on cholesterol-rich lipid rafts in the SARS-CoV-2-host interactions will provide valuable insights into pathogenesis and the identification of novel therapeutic targets.

Keywords: COVID-19, SARS-CoV-2 attachment and entry, cholesterol-rich lipid rafts, immune response, antiviral therapy

\section{INTRODUCTION}

The current Coronavirus disease 2019 (COVID-19) emergency is considered a global health threat (1). COVID-19 includes dyspnea, fever, headache, myalgia, and severe outcomes such as severe pneumonia, respiratory failure, multiple organ failure, including death (2). Severe Acute Respiratory Syndrome Coronavirus (SARS-CoV-2), the causal agent of COVID-19, belongs to the family of Coronaviridae (3) and is translated into four structural proteins (S, E, M, and N) and sixteen nonstructural proteins (NSP1-16) (4). The structural S protein or spike glycoprotein-mediated the coronavirus entry into host cells and comprised two subunits (5). The S1 subunit poses a receptor- 
binding domain (RBD) that specifically interacts with the host cell ACE-2 receptor, and the S2 subunit fuses the membranes of viruses and host cells (5). ACE-2 is a homolog of ACE-1 receptor that mediates the angiotensin II production to activate the reninangiotensin system (RAS) and plays a crucial role in cardiovascular diseases (6). The ACE-2 receptor is widely expressed in the heart, lung, and kidney (7) and functions during SARS-CoV-2 entry (8). Moreover, new evidence demonstrates the involvement of other receptors and cholesterol-rich lipid rafts in the SARS-CoV-2 internalization (9-17).

Due to the lipid rafts containing proteins and high concentrations of sphingolipids and cholesterol, the plasma membrane is less fluid than the rest (18). Thus, these rigid domains in the cell membrane provide a platform for diverse receptors involved in cell signaling and other functions (19-22). In addition, the lipid rafts contain specific receptors that mediate the internalization of pathogens through distinct entry mechanisms and modulate the lipid raft-dependent immune response $(23,24)$.

During SARS-CoV-2 infection, receptors relying on cholesterol-rich lipid rafts that contribute to the progression of inflammation are involved in viral entry $(9,11,15,16)$. Syndecans, a protein of the transmembrane proteoglycan family, facilitate the SARS-CoV-2 entry (15). Moreover, the SARS-CoV-2 S protein interacts with heparan sulfate and ACE-2 at the cell surface (10). Interestingly, receptors involved in the immune system, such as CD-147 and human Toll-like receptors (TLR), play an essential role in host cell entry and activation of the innate immune response to SARS-CoV-2 (11, 25). Hence, cholesterol-rich lipid rafts play an essential role in regulating the immune response and targeting antiviral therapy during SARS-CoV-2 infection.

The role of cholesterol-rich lipid rafts in the viral entry, assembly, and release was elucidated using cholesterol-lowering treatments (26-28). The efficient removal of cholesterol from these membrane microdomains leads to a disruption of the signaling pathways regulated by lipid rafts and the elimination of proteins associated with them (27, 29-31). In SARS-CoV-2 entry, the integrity of cholesterol-rich lipid rafts can modulate the interaction between the receptor and viral S protein (32). However, a better understanding of the role of cholesterol-rich lipid rafts in the host-SARS-CoV-2 interaction will provide valuable insights into novel mechanisms of viral entry and the development of new and alternate antiviral therapies.

\section{LIPID RAFTS AND CORONAVIRUSES}

Membrane microdomains enriched in cholesterol and glycosphingolipids are called lipid rafts (18). The cholesterolrich lipid rafts concentrate cellular proteins and lipids (19-22). In addition, cholesterol-rich lipid rafts are crucial cellular factors involved in viral replication $(31,33)$. The concentration of receptors and co-receptors in cholesterol-rich lipid rafts facilitates the virus fusion with host cell membranes, promoting efficient viral entry $(31,33,34)$.

Coronaviruses are diverse viruses that infect a broad range of organisms (35). Human coronaviruses (HCoV-229E, HCoVOC43, HCoV-NL63, and HCoV-HKU1) circulate worldwide, causing seasonal and usually mild respiratory tract infections (36). However, SARS-CoV, Middle East respiratory syndrome coronavirus (MERS-CoV), and SARS-CoV-2 are highly pathogenic, producing life-threatening respiratory pathologies and lung injuries $(35,37)$.

The cholesterol in the lipid rafts is indispensable for the internalization of the coronaviruses (38-41). Interestingly, cholesterol depletion from lipid rafts with cholesterol-lowering treatments such as methyl- $\beta$-cyclodextrin $(M \beta C D)$ affects the interaction between the SARS-CoV $S$ protein and the ACE-2 receptor (42). Also, a decrease of ACE-2 on the cell surface and reduction of the SARS-CoV entry was determined in $\mathrm{M} \beta C D$ pretreated cells (43). Therefore, based on their research, Glende et al. suggested that the difference in these data is due to their protocols, speculating that cholesterol-rich lipid rafts affect ACE2 protein conformation and the presentation of antigenic epitopes (42). Furthermore, the depletion of this cholesterol affects the spatial localization of ACE-2 in lipid rafts, demonstrating the importance of cholesterol-rich lipid rafts for efficient interaction between the viral surface protein and the cellular receptor (42).

Although Coronavirus envelope (E) protein is not related to viral entry, this protein plays a prominent role in viral morphogenesis and pathogenesis (44). SARS-CoV E protein can be translocated from the Golgi apparatus and endoplasmic reticulum to the cell surface, specifically in cholesterol-rich lipid rafts $(45,46)$. The $\mathrm{E}$ protein transmembrane domain is associated with membrane permeabilizing activity and inflammasome activation $(45,46)$. Since E protein is highly conserved among coronaviruses, this could be related to the membrane ion channel activity in the SARS-CoV-2 pathogenesis (47). The cholesterol depletion from lipid rafts decreases the virus entry and contributes to altering the membrane protein composition $(43,48)$; therefore, this process could impact the pathogenic mechanisms involving the E protein.

Overall, these results indicate that cholesterol-rich lipid rafts are required for entry and pathogenesis of the coronaviruses.

\section{THE ROLE OF CHOLESTEROL-RICH LIPID RAFTS IN SARS-CoV-2 ENTRY}

SARS-CoV-2 is a positive-sense RNA virus with two large overlapping open reading frames (ORF1a and ORF1b). This large single-stranded RNA genome of $\sim 30,000$ nt encodes two large polyproteins, ppla $(440-500 \mathrm{kDa})$ and pplab (740-810 $\mathrm{kDa}$ ), which are cleaved into the NSP1 to 11 and NSP12 to 16 , respectively (4). Some NSP contain functional domains, including the $3 \mathrm{C}$-like cysteine proteinase (3CL ${ }^{\text {pro }}$, NSP5), RNA-dependent RNA polymerase (RdRp, most of NSP12), 
nidovirus RdRp-associated nucleotidyltransferase ( $\mathrm{N}$ terminal of NSP12), helicase (Hel, NSP13), and exonuclease (ExoN, NSP14) $(4,49)$. Also, the SARS-CoV-2 genome encodes four structural proteins: spike surface glycoprotein (S), envelope (E), membrane $(\mathrm{M})$, and nucleocapsid $(\mathrm{N})$ that are essential for viral entry and assembly; and nine accessory proteins involved in the host immune response during infection $(4,49)$. SARS-CoV-2 attachment is the first step in the infection process, where the $S$ protein on the envelope of the virus recognizes the host cell receptors and mediates the viral entry (Figure 1) (49). S protein is cleaved by cellular proteases into the $\mathrm{S} 1$ and $\mathrm{S} 2$ subunits to give rise to trimers of the S1/S2 heterodimer (Figure 1) $(54,55)$. The S1 subunit contains the N-terminal domain (NTD) and the Cterminal domain (CTD), also called the receptor-binding domain (RBD), since it domain is responsible for binding the host receptor ACE-2 (54-56). The tip of the NTD of the SARSCoV-2 S protein has a ganglioside-binding domain (52 amino acid residues, 111-162) that could enhance virus attachment to lipid rafts in the host cell membrane and facilitate receptors binding (57), which will be discussed below. Moreover, the cleavage of SARS-CoV-2 S protein at the S1-S2 site produces the sequence TQTNSPRRAR $\mathrm{OH}_{\mathrm{H}}$, the binding site for neuropilin 1 (NRP1), an entry receptor found in the olfactory neuronal cells (53).
After attachment, the entry to the host cells of SARS-CoV-2 occurs via clathrin-mediated endocytosis in multiple cell types such as VERO, A549, and HEK-293T cells (58). In contrast, the caveolin-, clathrin-, endophilin A2-mediated endocytosis, and macropinocytosis might not be involved in SARS-CoV-2 entry (59). Bayati et al. used a Lentivirus pseudotyped with purified SARS-CoV-2 S protein prefusion-stabilized ectodomain (58). Therefore, the SARS-CoV-2 entry into the cell could depend on the distinct conformational states of the $S$ protein (Figure 1) $(60,61)$.

The clathrin-independent carriers/GPI-anchored-proteinenriched early endosomal compartments (CLIC/GEEC) is an essential pathway for cholesterol-rich lipid raft components (62, 63). Li et al. demonstrated that the CDC42-involved CLIC/GEEC pathway is unlikely to participate in the infection of SARS-CoV2 (59). Nevertheless, SARS-CoV-2 entry to host cells is cholesterol-rich lipid rafts dependent (59). Two pathways can regulate it: (1) the membrane fusion using proteases such as TMPRSS2, and (2) the endosomal pathway (where the cathepsin $\mathrm{B}$ and $\mathrm{L}(\mathrm{CatB} / \mathrm{L})$ is involved), which is less efficient than the fusion pathway (Figure 1) $(64,65)$. In this sense, CatL but not CatB facilities SARS-CoV-2 entry (Figure 1). When the TMPRSS2 expression is absent, the CatL is critical to viral entry mediated by $S$ protein; however, if TMPRSS2 is

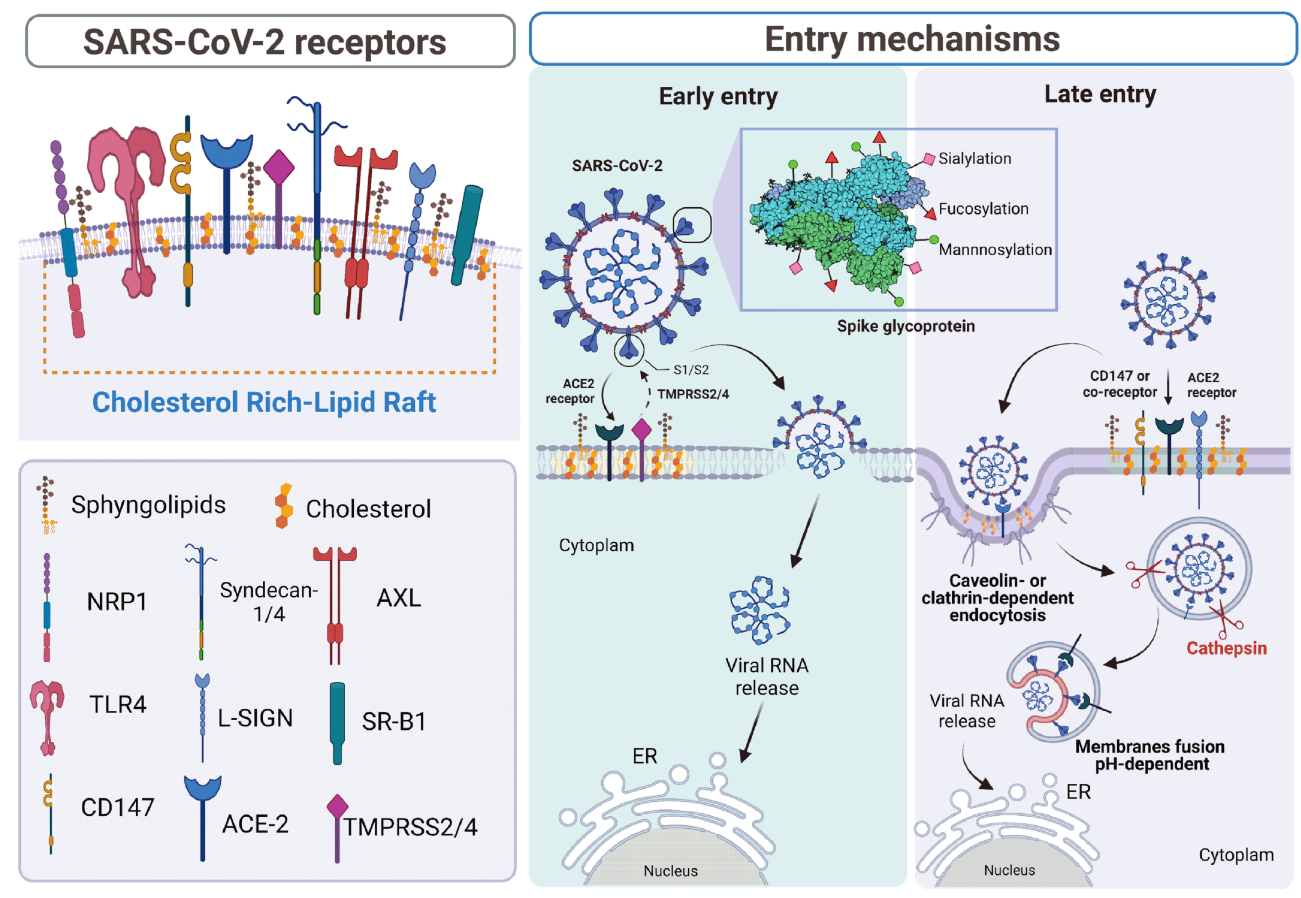

FIGURE 1 | Schematic representation of SARS-CoV-2 viral entry via receptors located on cholesterol-rich lipid rafts. In the left panel, we represent the different receptors and co-receptors located in the cholesterol-rich lipid rafts, described to participate and enhance the entry of SARS-CoV-2 (50). In the right panel, we represent the post-translational modifications of the spike protein enveloped in the attachment and the early and late entry of the virus. Early entry involves the major receptor ACE-2 and the transmembrane protease TMPRSS2/4 that promotes $\mathrm{pH}$-independent activation of the spike protein, which exposes the fusion peptide allowing fusion between cell and viral membranes (13, 51, 52). Late entry involves the ACE-2 receptor and a co-receptor such as HSPG (10), Syndecan-1/4 (15), NRP1 (53), L-SIGN (16), and SR-B1 (12). On the other hand, during the absence of ACE-2, the receptors CD-147 (11), AXL (14, 17), and probably TLR4 (9) activate the endocytic pathway mediated by clathrin or caveolin. In this endosomal compartment, the SARS-CoV-2 S protein is activated by the pH-dependent protease cathepsin, releasing the RNA into the cell cytoplasm (8). The graphical was elaborated using BioRender.com. 
expressed, the use of CatL is markedly diminished (66). The proteolytic activation by CatL depends on endosomal acidification and is inhibited when the endosomal $\mathrm{pH}$ increases (Figure 1) (66). In contrast, the TMPRSS2-mediated entry pathway is not affected by $\mathrm{pH}$, and it is more dependent and preferred over the CatL-mediated pathway for SARS-CoV-2 (66). Ou et al. also demonstrated that the furin-cleavage in the SARS-CoV-2-producing cell correlates with greater dependence on TMPRSS2 and lower dependence on CatL (66).

On the other hand, the cells from Nieman-Pick disease type $\mathrm{C}$ (NPC), a lysosomal storage disorder, have reduced lipid rafts. This could create unfavorable environments for SARS-CoV-2 infectivity (67). Hence, Ballout et al. hypothesized that the NPC cells might affect the trafficking of SARS-CoV-2 receptors such as ACE-2 and block SARS-CoV-2 fusion by the CatL leakage or affecting the proteolytic activity of CatL when the intralysosomal $\mathrm{pH}$ increases (67). In this regard, Nieman-Pick disease type C1 (NPC1) receptor, an endosomal membrane protein that regulates intracellular cholesterol traffic, interacts with SARS-CoV-2 N protein (68). The mechanism by which the SARS-CoV-2 N protein interacts with NPC1 is unknown. One possibility is that similarly to the interaction between the Ebola virus (EBOV)-glycoprotein (GP) and NPC1, SARS-CoV-2 could traffic the endocytic pathway for viral uncoating through the fusion of late endosomes and lysosomes $(68,69)$. It is not yet clear the specific role of NPC1 during SARS-CoV-2 infection. However, the antiviral compounds that interact with NPC1, such as carbazole SC816 and sulfides SC073 and SC198 (drugs used to elucidate the interaction between EBOV-GP and NPC1) can reduce SARS-CoV-2 infection with a good selectivity index in human cell infection models $(68,70)$. This receptor was found in a genome-scale CRISPR loss-of-function screen performed to identify host factors required for SARS-CoV-2 viral infection of human alveolar basal epithelial carcinoma cells (71). Thus, the role of NPC1 in cholesterol regulation is essential during SARSCoV-2 infection $(67,71,72)$. Also, the panel of the top-ranked genes screened by Daniloski et al. revealed that RAB7A regulates cell surface expression of ACE-2, likely by sequestering this SARS-CoV-2 receptor in endosomal vesicles (71). RAB7A interacts with the SARS-CoV-2 NSP7 protein (73), a viral protein required for the RdRP complex assembly (74). Since the RAB7A is required for exosome secretion (75), SARS-CoV-2 could use an exosome pathway as a route of entry or egress, similar to other viruses (76). Exosomes isolated from COVID-19 patients contain the SARS-CoV-2 RNA and proteins implicated in the exosomal cargo (77). These results suggest that exosomes are involved in the mechanisms associated with tissue damage and multiple organ injury in COVID-19 patients (77).

Upon cell entry, cholesterol-rich lipid rafts found on the outer leaflet of the plasma membrane can play an essential role in membrane fusion between the SARS-CoV-2 particle and the early endosome to allow the viral genome to be released into the cytoplasm (Figure 1). In this sense, the upstream helix (UH) region is removed by $\mathrm{S} 2$-proteolytic cleavage to activate irreversible conformational changes and initiate membrane fusion $(49,60)$. This SARS-CoV-2 replication step depends on the cholesterol-rich lipid rafts and endosomal acidification. The cholesterol-rich lipid rafts are found on the luminal side of the endosome (78-80). Glycerophospholipid bis(monoacylglycerol) phosphate (BMP) is also named lysobisphosphatidic acid (LBPA) (81). BMP is enriched in the internal membranes of the late endosome/lysosome, regulating cholesterol distribution on the lipid rafts (81). The accumulation of BMP reduces the expression of ATP-binding cassette transporter G1 (ABCG1), a lipid transporter responsible for lung lipid homeostasis and acting as a protective factor during infections $(82,83)$. Cholesterol-rich lipid rafts are determinants for SARS-CoV-2 interaction with the cellular receptor ACE2 (Figure 1) (59). BMP regulation of these cholesterol-rich membrane domains could impact viral entry (81). BMP regulates the cholesterol efflux to HDL in macrophages and the production of oxysterols such as 25-Hydroxycholesterol (25-HC) (84). 25-HC is a potent inhibitor of SARS-CoV-2 replication by restricting the $\mathrm{S}$ protein catalyzed membrane fusion via blockade of cholesterol export in the late endosomes (85). 25-HC is the product of cholesterol oxidation by the enzyme cholesterol-25-hydroxylase and can control sterol biosynthesis by regulating Sterol Regulatory Element Binding Protein (SREBP) (86). Zu et al. suggested that $25-\mathrm{HC}$ could be considered a risk marker for the severity due to its high concentration in a fatal COVID-19 patient and SARS-CoV-2 infected hACE2 mice (87). 27hydroxicholesterol (27-HC) is accumulated in plasma membrane lipid rafts when exogenously added (88). 27-HC could have important implications for modifying the structure and function of membrane lipid-protein clusters during SARSCoV-2 infection (88). Although the SARS-CoV-2 particle is not directly inactive by $27-\mathrm{HC}$, this modifies cell structures of the lipid rafts by the accumulation of cholesterol, inducing a transient modification of the endosomal membrane composition and function to inhibit SARS-CoV-2 replication (88). Interestingly, Marcello et al. demonstrated that blood levels of 27-HC were decreased in patients with severe COVID-19 (88). Also, they showed an increased serum level of 7-ketocholesterol and $7 \beta$-hydroxycholesterol, recognized in vivo markers of oxidative stress, was observed in the COVID-19 patients but not in pauci- and asymptomatic patients (88).

Even though knowledge about SARS-CoV-2 entry still grows rapidly, the studies presented and discussed above may help understand the role of cholesterol-rich lipid rafts in this viral replication process (Figure 1).

\section{CHOLESTEROL-RICH LIPID RAFTS PROVIDE A PLATFORM TO CONCENTRATE SARS-CoV-2 RECEPTORS}

Cholesterol-rich lipid rafts serve as a platform for the functional organization of the receptors involved in the cell signaling, synaptic activity, immune response, membrane trafficking, and cytoskeleton remodeling $(19,89-92)$. The pathogen interplay 
with cholesterol-rich lipid rafts modulates many cellular processes. During virus entry into the cell, the cholesterol-rich lipid rafts contain receptors and co-receptors that interact with viral surface proteins $(31,93)$. Moreover, the entry of enveloped and non-enveloped viruses into host cells occurs through fusion or endocytosis mediated by caveolin or clathrin located in the lipid-rich microdomains (94). In this regard, the study of cholesterol-rich lipid rafts is rapidly expanding and has again become an attractive topic for SARS-CoV-2 research. Hence, the role of receptors for SARS-CoV-2 entry localized and distributed on cholesterol-rich lipid rafts during infection will be discussed below (Figure 1 and Table 1).

\section{Angiotensin-Converting Enzyme-2 (ACE-2)}

The ACE-2 protein, localized in cholesterol-rich lipid rafts, is used as a functional receptor for human coronaviruses $(48,107)$. ACE-2 is a homolog of ACE-1 receptor that mediates the angiotensin II production to activate the renin-angiotensin system (RAS) and plays a crucial role in cardiovascular diseases (6). Also, the ACE-2 receptor is widely expressed in various organs such as the heart, lung, kidney, and liver (108, 109). The interaction between the host cell and SARS-CoV-2 is closely identical to SARS-CoV, which also uses the ACE-2 as a cellular receptor (Figure 1). It facilitates virus entry via caveolin- or clathrin-dependent endocytosis. (51, 52). Although the predominant symptoms of SARS-CoV-2 infection are respiratory, multiple organ injuries such as renal and hepatic abnormalities and cardiac lesions are observed among COVID19 patients (109). This tropism is attributed to the presence of the ACE-2 receptor in various organs (108). However, the fact that the participation of other receptors may enhance the SARS-CoV2 entry is not ruled out. Recognizing mannosylated N-glycan and $\mathrm{O}$-glycan on the $\mathrm{S}$ protein by cellular receptors found in the cholesterol-rich lipid rafts could facilitate the SARS-CoV-2 entry (Figure 1) (50). Therefore, the quick adaptation of SARS-CoV-2 to cell receptors could be associated with new pathologies or more severe diseases. In the following, we will describe new evidence on the role of other receptors in SARS-CoV-2 entry.

\section{Transmembrane Serine Proteases (TMPRSS)}

The TMPRSS subfamily includes membrane-anchored serine proteases belonging to the serine protease type II family that possesses an N-terminal transmembrane domain and a Cterminal extracellular chymotrypsin serine protease domain (95). This subfamily comprises seven members: TMPRSS1/ hepsin, TMPRSS2, TMPRSS3, TMPRSS4, TMPRSS5/spinesin, mosaic serine protease large-form (MSPL), and enteropeptidase

TABLE 1 | Summary of the cellular receptors from cholesterol-rich lipid rafts that are involved in SARS-CoV-2 entry.

\begin{tabular}{|c|c|}
\hline Receptor & Cellular function \\
\hline ACE-2 & $\begin{array}{l}\text { ACE-2 is a negative regulator of RAS and a catalyst for converting } \\
\text { angiotensin II to angiotensin 1-7. ACE- } 2 \text { is expressed in various organs } \\
\text { such as the heart, lung, kidney, liver, etc. }\end{array}$ \\
\hline TMPRSS2/ & TMPRSS are vital regulators of mammalian development and \\
\hline 4 & $\begin{array}{l}\text { homeostasis in different tissues as the liver, lungs, pancreas, intestinal } \\
\text { tract, and salivary glands. }\end{array}$ \\
\hline HSPG & $\begin{array}{l}\text { HSPG participates in multiple functions such as cellular adhesion and } \\
\text { motility; moreover, they serve as receptors for endocytosis and are } \\
\text { also involved in the control of numerous events that occur during } \\
\text { inflammation }\end{array}$ \\
\hline Syndecan- & Syndecans are expressed in various cellular sites and participate \\
\hline $1 / 4$ & $\begin{array}{l}\text { during adhesion between cell and extracellular matrix, cell-cell } \\
\text { adhesion, cell migration, and regulation of the inflammatory response. }\end{array}$ \\
\hline TLR-4 & $\begin{array}{l}\text { TLR4 is a key receptor that induces the pro-inflammatory response, } \\
\text { can mediate inflammation by both exogenous and endogenous } \\
\text { ligands, and is associated with chronic and acute diseases, promoting } \\
\text { amplification of the inflammatory response. }\end{array}$ \\
\hline CD147 & $\begin{array}{l}\text { CD147 is a transmembrane glycoprotein member of the } \\
\text { immunoglobulin superfamily implicated in various physiological and } \\
\text { pathological conditions due to its regulation of cell-cell recognition, cell } \\
\text { differentiation, and tissue remodeling. }\end{array}$ \\
\hline NRP1 & $\begin{array}{l}\text { NRP1 is a pleiotropic transmembrane polypeptide that acts as a } \\
\text { growth factor or a cofactor in fibroblasts, platelets, hepatocytes, etc. }\end{array}$ \\
\hline L-SIGN & $\begin{array}{l}\text { L-SIGN is a type II C-type lectin receptor involved in cell adhesion and } \\
\text { pathogen recognition. It is expressed in dendritic cells, epithelial cells, } \\
\text { lungs, liver, lymph nodes, and placenta. }\end{array}$ \\
\hline AXL & $\begin{array}{l}\text { AXL is a receptor tyrosine kinase; its activation promotes } \\
\text { homodimerization, causing tyrosine autophosphorylation or } \\
\text { phosphorylation of downstream targets, activating signaling pat }\end{array}$ \\
\hline
\end{tabular}

SR-B1 SR-B1 is the cell-surface HDL receptor that mediates a selective uptake system for cholesterol and other lipids in various cells, such as fibroblasts, hepatocytes, macrophages, adrenal, and alveolar cells.
ACE-2 binds to the S protein-RBD of SARS-CoV-2, facilitating virus entry via caveolin- or clathrin-dependent endocytosis.

TMPRSS2 and TMPRSS4 enhance cellular-virus membrane fusion by inducing protein $\mathrm{S}$ cleavage and exposing the fusion peptide, which interacts with the ACE-2 receptor.

The interaction between SARS-CoV-2 spike protein and HSPG is necessary for the viral entry via endocytosis ACE-2-dependent.

References

Syndecan-1/4 interacts with the S1 subunit of SARS-CoV-2 spike protein, an essential viral attachment factor, and mediator of viral entry.

TLR4 interacts with the S1 subunit of spike protein and is involved in SARS-CoV-2 entry, even if the cell line lacks the ACE-2 receptor. However, evidence on the mechanism of entry used by the virus is lacking.

S protein of SARS-CoV-2 interacts with the CD147 receptor and facilitates virus entry via endocytosis even in the absence of the ACE-2 receptor.

NRP1 enhances SARS-CoV-2 entry and infectivity only in coexpression with ACE-2 and TMPRSS2.

L-SIGN binds to high-mannose-type $\mathrm{N}$-glycans present in the spike protein of SARS-CoV-2, favoring the viral entry in the presence of the ACE-2 receptor.

The NTD of the SARS-CoV-2 spike protein binds to AXL, independently of the presence of the ACE-2 receptor. However, low levels of the ACE-2 receptor synergize with the expression of the AXL to potentiate SARS-CoV-2 infection.

The RBD of the SARS-CoV-2 S protein has an affinity for cholesterol and HDL components, enhancing the entry of the virus

into the cell through SR-B1 only when ACE-2 es expressed.
(8)

$(10,96,97)$

$(15,98)$

$(99-102)$

$(14,17$, 
(110). TMPRSS receptors are expressed in various tissues such as the liver, lungs, pancreas, intestinal tract, and salivary glands (95). In addition, TMPRSS are vital regulators of the mammalian development, homeostasis, and host factors involved in the entry of coronaviruses (111).

The TMPRSS2 and TMPRSS4 receptors activate the glycoproteins of influenza virus, SARS-CoV, and MERS-CoV to enhance the viral entry, promoting the syncytia formation and cell tropism since these receptors are expressed in epithelial cells of the respiratory and intestinal tracts (112-115). Interestingly, TMPRSS2 contains a potential palmitoylation residue in the cytoplasmic tail responsible for its localization in cholesterol-rich lipid rafts (116). Moreover, this receptor is associated with ACE2 . Thus, both receptors are membrane-embedded of these microdomains (116). Hence, cellular entry and susceptibility of the coronaviruses can be defined by the expression of both ACE2 and TMPRSS receptors.

Hoffmann et al. demonstrated that SARS-CoV-2 uses the TMPRSS2 for S protein priming, and that the infection of lung cells with this virus can be blocked by a TMPRSS2 inhibitor (Figure 1) (64). TMPRSS2-dependent SARS-CoV-2 entry may be due to precleavage of the furin-dependent Subunit1/Subunit2, which is essential for the releasing viral RNA into the cell cytoplasm (64). Zang et al. described that both TMPRSS2 and TMPRSS4 enhance membrane fusion by inducing $S$ protein cleavage, exposing the fusion peptide in gastrointestinal tract cells after binding to the ACE-2 receptor (13). Also, TMPRSS4, one of the most significantly correlated genes with the ACE-2 receptor expression (117), enhanced the SARS-CoV-2 entry into human small intestinal enterocytes, while some COVID-19 patients shed high levels of viral RNA in feces (13). However, the SARS-CoV-2 particles released in the feces are rapidly inactivated by the low $\mathrm{pH}$ of gastric fluids, consistent with the previous reports on SARS-CoV and MERS-CoV infections (13). These findings suggest that the intestine is a potential site of SARS-CoV-2 replication, where TMPRSS4 plays an important role, contributing to local and systemic disease and gastrointestinal symptoms progression (13).

The salivary glands from SARS-CoV-2-infected patients have the ACE-2 and TMPRSS receptors overexpression (118). Also, the ultrastructural analysis of the ductal lining cell cytoplasm, acinar cells, and ductal lumen was performed by electron microscopy, a tool used to identify viral particles (119), revealed coronavirus-like particles (118). These findings demonstrated that the salivary glands are a reservoir for SARS$\mathrm{CoV}-2$, supporting the use of the saliva as a diagnostic method for COVID-19 and the role of this biological fluid in spreading the disease (118). TMPRSS3, TMPRSS4, TMPRSS5, and TMPRSS7 correlate with the ACE-2 expression in salivary glands, and these receptors are overexpressed when the basal cells in the oral cavity are differentiated to suprabasal cells (120). However, this cellular differentiation prepares the cells to shed from the oral cavity (121). Furthermore, the stratified squamous cells of the oral cavity are not linked to specific symptoms and shed continuously in the saliva, which could result in asymptomatic COVID-19 patients $(120,121)$.
The proteolytic activation of S protein was insufficient to fuse the viral membrane to the cell that does not express TMPRSS receptor, confirming the importance of TMPRSS in SARS-CoV-2 entry (122). In contrast, the SARS-CoV-2 S protein was activated, exposing its fusion peptide and facilitating early penetration of the virus into the cytosol, $\mathrm{pH}$-independent, in the cells expressing TMPRSS2 (122). Thus, TMPRSS2 expression dictates the entry route of SARS-CoV-2 to infect the host cells and could have implications in the adaptation and expanded tropism of the virus (122).

The SARS-CoV-2 S1/S2 cleavage site is mutated when the virus is serially passaged in TMPRSS2-deficient cells (123). This event led to a loss of sensitivity to the TMPRSS2 receptor (123). Also, this mutation prevents direct fusion mediated by TMPRSS2, showing a narrow range of the cell tropism (123). Therefore, more attention should be paid to Vero cells in the isolating and propagating SARS-CoV-2, developing vaccines, and in vitro evaluation of the antiviral activity of drugs against this virus due to the possibility that some viral genomes accumulate mutations in the S gene by the absence of the TMPRSS2 receptor (123). In summary, TMPRSS receptors located in cholesterol-rich lipid rafts are critical host factors involved in the mechanisms of SARS-CoV2 entry. They can be an essential study target to understand the pathogenicity of COVID-19.

\section{Heparan Sulfate}

Heparan sulfate proteoglycans (HSPG) are linear sulfated polysaccharides found on the cholesterol-rich lipid rafts (97). HSPG participates in the cellular adhesion and motility, endocytosis, and the control of numerous events during inflammation $(96,97)$. Due to the negative charge attributed by the sulfated chains, HSPG can interact electrostatically with the basic residues of viral glycoproteins and capsid, favoring the interaction between the viral particle and their specific entry receptor (124). HSPG facilitates initial viral particle-host cell interactions with influenza virus, dengue virus, herpes virus, and some human coronaviruses (124).

The S protein from NL63 and SARS-CoV binds to HSPG, an important co-receptor that facilitates virus internalization. The sialic acid is used as an attachment factor for MERS-CoV entry (125-127). The SARS-CoV-2 S protein binding to the ACE-2 receptor is an HSPG-dependent pathway and necessary for efficient viral replication (Figure 1) (10). Interestingly, the $\mathrm{RBD}$ of the SARS-CoV-2 S protein can bind HSPG in a length- and sequence-dependent manner (128). This interaction can be drastically reduced by treating heparin lyases that degrades cell-surface HSPG (10). Additionally, a variety of HSPGs may further modulate the tissue tropism and susceptibility to COVID-19 in the population (10).

\section{Syndecans}

Syndecans are membrane surface proteins that belong to the proteoglycan family, located in cholesterol-rich lipid rafts (129). However, syndecans can be found at various cellular sites, containing other glycosaminoglycan structures and participating in adhesion between cell-extracellular matrix, cell-cell, cytoskeleton- 
syndecan proteins, and cell migration (98, 129). Syndecan-1 can mediate the inflammatory response by binding to inflammationrelated factors, negatively regulating leukocyte migration and adhesion, and modulating the cytokine gradient activity (130).

Syndecan-4 negatively modulates the activation of the antiviral immune response, inhibiting especially the type 1 interferon response (IFN-1) induced by retinoic acid-induced gene 1 (RIG-1) (131). Syndecans are involved in the viral attachment of other viruses (132-135).

Due to the role of syndecans in viral infections, Hudák et al. explored the possible interactions between SARS-CoV-2 S protein and the isoforms of syndecans, identifying that syndecan-3 and -4 facilitated the uptake of SARS-CoV-2 (Figure 1), and syndecan-4 specifically interacts with the $S 1$ subunit of the $\mathrm{S}$ protein to mediate SARS-CoV-2 internalization (15). Moreover, syndecan-1 mediates cell attachment of S protein in lung epithelial cells (136). The hypoxia could modulate the expression of ACE-2 and syndecan-1 receptors, suggesting that low oxygen levels in COVID-19 patients are a defense mechanism to reduce the expression of entry receptors and attachment factors located in cholesterol-rich lipid rafts (136). Notably, the distribution of syndecan-4 is ubiquitous, and its expression is abundant in the lungs, one of the target organs of SARS-CoV-2 (137). Syndecan-4 would enhance the virus entry into lung epithelial cells and the modulation of the immune response, contributing to the pathogenesis and the severe lung damage in SARS-CoV-2-infected patients (138). The crucial role of syndecan receptors in SARS-CoV-2 entry is evident; however, it remains to be elucidated whether syndecan- 1 and -4 in SARSCoV-2 entry can modulate negatively or positively the signaling of the antiviral immune response (Figure 2).

\section{Human Toll-Like Receptors (TLRs)}

TLRs are a family of integral membrane glycoproteins involved in the innate immune response (147). TLR possesses a leucinerich extracellular region that interacts with a ligand such as pathogen-associated molecular patterns (PAMPs) from various pathogens, including bacteria, fungi, parasites, and viruses, promoting receptor dimerization and subsequent recruitment signaling molecules (147). The TLR family comprises 12 members, which are expressed in distinct cellular compartments. TLR1, TLR2, TLR4, TLR5, and TLR6 are expressed on the cell surface, whereas TLR3, TLR7, TLR8, and TLR9 are expressed in vesicles and the endoplasmic reticulum intracellularly (148). The TLRs are localized in the cholesterolrich lipid rafts on the cell surface (101). In this place, the cyclodextrins $(\mathrm{M} \beta \mathrm{CD})$ can sequester cholesterol, affecting the activation of inflammatory response and cytokine secretion and chemokines (101). In this regard, the proteins related to vesicular trafficking, such as the Soluble $N$-Ethylmaleimide-Sensitive Factor Attachment Protein Receptor (SNARE), syntaxin 4, and SNAP-23, are clustered in cholesterol-rich lipid rafts where they participate in cytokine release $(149,150)$. When the cholesterolrich lipid rafts localized in the macrophage plasma membrane are disrupted, the phagocytic cup formation is altered, and TNF secretion is reduced $(149,150)$. During SARS-CoV-2 infection, cholesterol depletion of lipid rafts with $M \beta C D$ could affect the TLR clusters and the effective activation of kinase complexes (IKK) (Figure 2) (59). It could also have an impact on the transcription factors (Nuclear factor-kappa $\beta$ (NF-kB) and Interferon regulatory factor (IRF), involved in the activation of genes related to pro-inflammatory response and secretion of cytokines and chemokines (Figure 2) (101). TLR4 is a key receptor that induces the pro-inflammatory response by exogenous and endogenous ligands and is associated with chronic and acute diseases, promoting amplification of the inflammatory response (100).

The viral glycoproteins or capsid proteins can interact with TLR4 to activate its signaling pathway and an uncontrolled inflammatory response, leading to virus disease severity (151). Interestingly, the TLR4-mediated signaling pathway could benefit multiple steps of the virus life cycle, such as enhancing viral particle release from the cell or preventing premature cell apoptosis, since cell survival factors can also be activated via TLR4 (151).

Due to the acute inflammation in SARS-CoV-2 pathogenesis, Choudhory et al. performed an in silico analysis of the interaction between the $S$ protein and cell surface receptors of the innate immune response, especially TLRs. Choudhory et al. demonstrated by molecular docking a significant binding between the S protein and TLR1, TLR4, or TLR6, of which the SARS-CoV-2 S protein-TLR4 interaction possessed the strongest binding energy (Figure 2) (140). Even though experimental evidence confirming the interaction between the $S$ protein and TLRs is lacking, the main cytokines involved in patients with severe COVID-19 are products of TLR4 viral signaling: IL-6 and TNF- $\alpha$ (Figure 2) (140). In addition, the S1 subunit of S protein promotes TLR4 activation inducing the expression and secretion of TNF- $\alpha$ mRNA, which was significantly suppressed with a TLR4 antagonist (Figure 2). Curiously, this effect was not observed when a TLR2 antagonist was used. Thus, SARS-CoV$2 \mathrm{~S}$ protein-TLR4 interaction is involved in the inflammatory response triggered by COVID-19 (102). Also, this interaction would promote endocytosis of the virus and activation of the TLR4 signaling cascade to trigger the pro-inflammatory response (Figure 2) (101). SARS-CoV-2 can infect the cerebral cortical neurons, cells that do not express ACE-2 receptor but contain TLR4 receptor, and activate the pro-inflammatory response, suggesting that the TLR4 is involved in SARS-CoV-2 entry and could be related to the neurological manifestations of COVID-19 (99). Further studies are needed to clarify the involvement of TLR4 as a co- or receptor for SARS-CoV-2. Moreover, TLRs are involved in the activation of the immune response causing a cytokine storm in COVID-19 patients, where TLR-3, -7, -8 through viral RNA recognition triggers the activation of JAK/ STAT, NF-kB, AP-1 signaling pathways resulting in the amplification of pro-inflammatory cytokines $(152,153)$. Thus, TLR7/8 antagonist drugs (Hydroxychloroquine, HCQ; a TLR blocker) could limit SARS-CoV-2 infection $(152,153)$. In this sense, HCQ can inhibit endosomal TLR3, -7, -8, and -9 signaling, controlling inflammation in COVID-19 patients and mitigating the detrimental effects of viral infection $(152,153)$. 


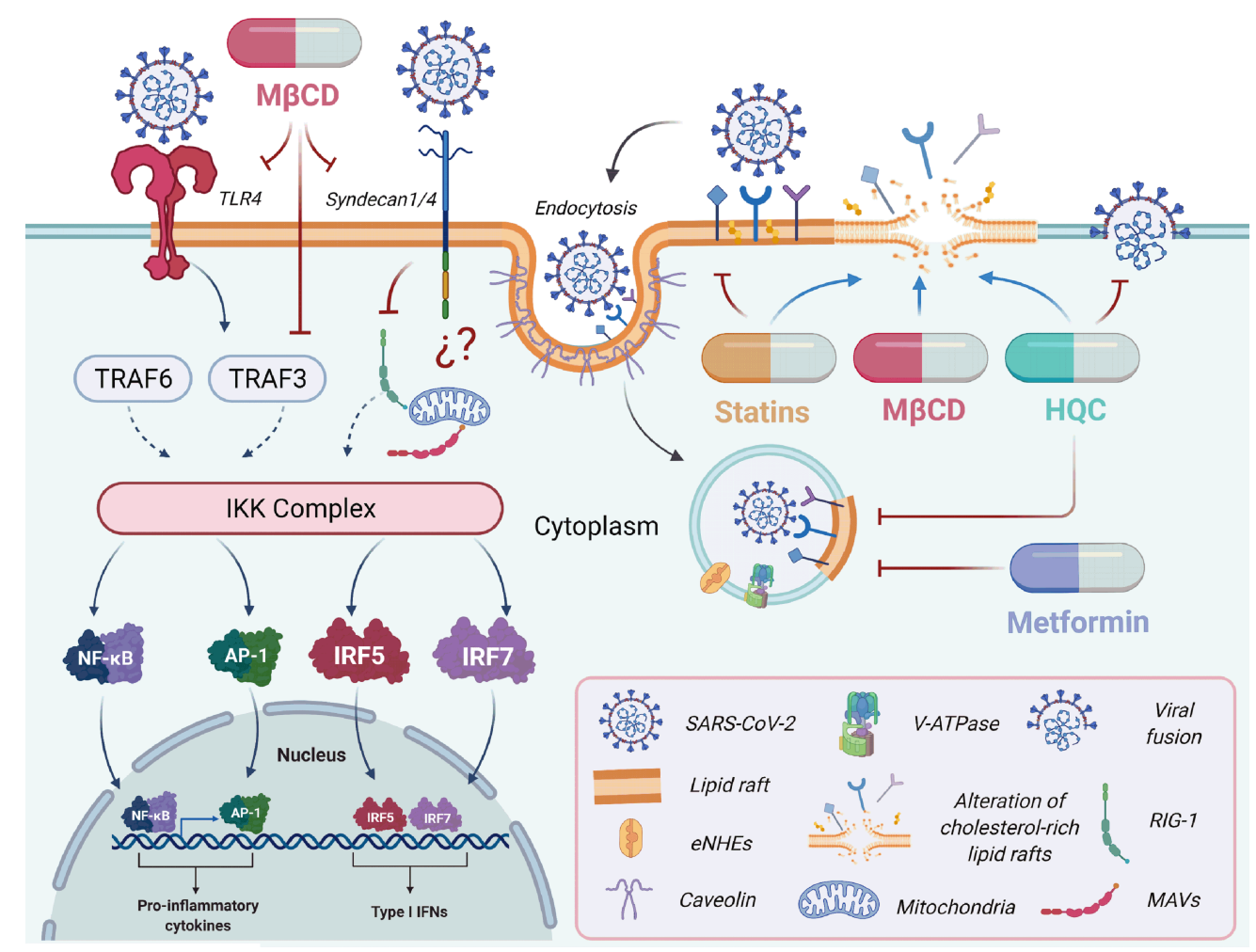

FIGURE 2 | The potential therapeutics of drugs targeting cholesterol-rich lipid rafts in SARS-CoV-2 infection. Therapeutic strategies to inhibit viral replication, including the use of lipid-lowering drugs as antivirals candidates, are based on the study of lipids and their importance in the viral cycle (139). The lipid raft microdomains are primarily associated with the viral entry and play an essential role during other viral cycle stages, such as cellular signal transduction. SARS-CoV-2 entry depends on binding to ACE2; other receptors such as TLR4 or Syndecan 1/4 are involved in pro-inflammatory cytokines (140) and inflammation response (141). Interestingly, cholesterol depletion of lipid rafts using cholesterol-lowering treatments such as methyl- $\beta$-cyclodextrin (M $3 C D)(42,59)$, statins (41), and hydroxychloroquine (HQC) (142) affect the interaction between the SARS-CoV-2 spike protein and the ACE-2 receptor. Metformin (143) and HQC (144) can increase the $\mathrm{pH}$ values of endosomes acting on the Vacuolar ATPase (V-ATPase) and endosomal $\mathrm{Na}+/ \mathrm{H}+$ exchangers (eNHEs). This mechanism inhibits the viral infection by increasing the cellular $\mathrm{pH}$ and interfering with the endocytic cycle $(143,145,146)$. The graphical was elaborated using BioRender.com.

\section{Dendritic Cell-Specific Intercellular Adhesion Molecule-3-Grabbing Nonintegrin Related (L-SIGN or DC-SIGNR)}

Also known as CD209L, L-SIGN is a type II C-type lectin receptor found in cholesterol-rich lipid rafts and expressed in dendritic cells, epithelial cells, lungs, liver, lymph nodes, and placenta (104). L-SIGN can bind to high mannose oligosaccharides through its carbohydrate recognition domain, and it is involved in the attachment of viral glycoproteins (104). L-SIGN participates in SARS-CoV infection and pathogenesis, where the presence of ACE-2 is required for efficient virus entry into the cell (154). Thus, the role of L-SIGN as a co-receptor enhances viral entry (154). Interestingly, a genetic risk association study revealed that individuals homozygous for the CD209L receptor tandem repeats were less susceptible to SARS$\mathrm{CoV}$ infection (155). Hence, the ligand-binding capacity dependent on homo- or heterozygosity of L-SIGN plays a protective role in affecting the susceptibility to SARS-CoV infection (155).
L-SIGN is an endothelial receptor for SARS-CoV-2 that could contribute to the COVID-19 associated coagulopathy (16). Notably, high-mannose-type N-glycans present in the SARS$\mathrm{CoV}-2 \mathrm{~S}$ protein play a decisive role in the binding to L-SIGN (Figure 1), suggesting that blockade of L-SIGN would serve as a novel antiviral therapy option (16). The SARS-CoV-2 mutation at the D614G glycosylation site is one of the more infectious dominant variants in the early phases of the pandemic (156). In this regard, this mutation raises the glycosylation of $S$ protein, enhancing virus entry into the cell, contributing to the severity of SARS-CoV-2 infection $(156,157)$.

\section{AXL Receptor Tyrosine Kinase (AXL)}

AXL is localized in cholesterol-rich lipid rafts, and its activation promotes homodimerization, causing tyrosine auto- or phosphorylation of downstream targets (105). AXL is expressed ubiquitously in several cell types, and its function depends on the specific cell/tissue type (105). This receptor participates in (1) virus binding and internalization; and (2) viral replication by antagonizing the IFN-1 pathway (158). The 
AXL receptor, expressed on lung epithelial cells specifically, can bind to the SARS-CoV-2 spike protein through their N-terminal domain to promote viral entry, independently of the presence of the ACE-2 receptor (Figure 1) (17). Therefore, the interaction between the SARS-CoV-2 S protein and the AXL receptor may support an essential role of AXL during infection of human pulmonary and bronchial tissues (17). In addition, low levels of the ACE-2 receptor synergize with the expression of the AXL receptor to potentiate SARS-CoV-2 infection (14). Together, these studies confirm that the AXL receptor is essential in SARS-CoV-2 entry into lung cells, and this mechanism could be effectively disrupted in human lung cells by the AXL inhibitors.

\section{High-Density Lipoprotein (HDL) Scavenger Receptor B Type 1 (SR-B1)}

SR-B1 is the cholesterol-rich lipid rafts HDL receptor that mediates a selective uptake system for cholesterol and other lipids in various cells, such as fibroblasts, hepatocytes, macrophages, adrenal, and alveolar cells (106). The RBD of the SARS-CoV-2 S protein has a particular affinity for cholesterol and HDL components, enhancing the virus entry into the cell through SR-B1, suggesting that this interaction is dependent on the presence of membrane cholesterol (Figure 1) (12). In addition, ACE-2 and SRB-1 are co-expressed in multiple susceptible tissues (159). Therefore, this evidence further supports the important role of cholesterol-rich lipid rafts and receptors that regulate lipid entry into the cell to enhance the SARS-CoV-2 entry.

\section{Other Immune Receptors}

CD147 is a member of the immunoglobulin superfamily, located in cholesterol-rich lipid rafts (103). CD147 facilitates SARS-CoV infection (160). It can bind to SARS-CoV-2 S protein to promote the endocytosis-dependent viral internalization even in the absence of the ACE-2 receptor, revealing a novel virus entry route (11).

Ahmetaj et al reported that the cardiorenal tissues and endothelial cells express the CD147 and ACE-2 genes required for SARS-CoV-2 entry (Figure 1) (161). Interestingly, ACE-2 decreases with age in some tissues, and CD147 increases with age in endothelial cells, suggesting that CD147 expression in the vasculature may explain the heightened risk for COVID-19 severe with age (161). Moreover, CD147 is expressed in the kidney of COVID-19 patients, where its distribution is expanded from the basolateral to the circumferential pattern, including interfacial and apical sides (162). Thus, CD147 apical presentation likely contributes to SARS-CoV-2 internalization from that lumen side into the cytoplasm of tubular epithelial cells (162).

Neuropilin-1 (NRP1) is a pleiotropic transmembrane polypeptide that acts as a growth factor or cofactor in fibroblasts, platelets, and hepatocytes (163). NRP1 is involved in the SARS-CoV-2 infection, and in contrast with ACE-2 and TMPRSS2 receptors, NRP1 does not enhance SARS-CoV-2 entry in cell lines that only express this receptor (53). However, when
NRP1 is co-expressed with ACE-2, and TMPRSS2 the SARS$\mathrm{CoV}-2$ infection significantly increases, defining its role as an essential co-receptor for viral entry (Figure 1) (53). Since there is limited evidence, further studies are needed to clarify the interaction between the SARS-CoV-2 S protein and NRP1 receptor and how it facilitates viral entry $(50,53)$.

\section{TARGETING CHOLESTEROL-RICH LIPID RAFTS AS POTENTIAL THERAPEUTICS IN SARS-CoV-2 INFECTION}

Lipidomic evidence suggests a remodeling of lipid metabolism in coronavirus-infected human cells (164). This alteration is associated with aberrant lipid metabolism in obese patients who develop a decreased immune response, which increases the severity of COVID-19 (165). Cholesterol localized in the lipid rafts is an essential entry factor for coronaviruses, both in vitro and in vivo $(42,48,166)$, and a determinant of the SARS-CoV-2 pathogenesis and replication (167).

Therapeutic strategies to inhibit viral replication, including the use of lipid-lowering drugs as antivirals candidates, are based on the study of lipids and their importance in the viral cycle (139). Although, as previously discussed, this review is focusing on cholesterol-rich lipid rafts and the SARS-CoV-2 entry (9-17), the essential role of cholesterol during SARS-CoV-2 replication and egress cannot be ruled out $(71,85,168-171)$. It is essential to mention here that although a notable amount of work has been carried out on the relationship between SARS-CoV-2 entry and lipid rafts, few studies have been published focusing on the role of the lipid rafts in SARS-CoV-2 replication and egress.

Cholesterol is an essential component of host cell membranes involved in tuning membrane fluidity, thickness, and permeability to regulate membrane function (172). The viral replication complexes are RNA virus-induced membrane structures where viral genome replication and morphogenesis occur (119). The formation of the replication complex requires cholesterol, a product of fatty acid metabolism $(26,173)$. Williams et al. demonstrated that the inhibition of fatty acid metabolism by orlistat [Food and Drug Administration (FDA)approved drug that inhibits gastric lipases and fatty acid synthase (FASN)], TOFA [a competitive inhibitor of acetyl-CoA carboxylase (ACC)], A922500 (a potent inhibitor of diacylglycerol acyltransferase 1 (DGAT1) or VPS34-IN1 [an inhibitor of vacuolar protein sorting 34 (VPS34-IN1)], interferes with the formation of dsRNA-positive SARS-CoV-2 replication complexes (171). Transmembrane protein 41B (TMEM41B) likely contributes to SARS-CoV-2 replication complexes formation through cholesterol trafficking to facilitate host membrane expansion and curvature (173).

Lipid droplets store neutral lipids and cholesterol, and they are a platform for SARS-CoV-2 assembly and replication (174). Additionality, modulation of lipid droplets formation by inhibition of DGAT1 using A922500 can block SARS-CoV-2 replication and reduce the production of mediators proinflammatory response $(171,174)$. 
On the other hand, Daniloski et al. identified a group of host genes (RAB7A, NPC1, ATP6AP1, ATP6V1A, CCDC22, and PIK3C3) implicated in the upregulation of the cholesterol synthesis pathway during SARS-CoV-2 infection (71). A parallel genome-scale CRISPR-Cas9 knockout screen revealed genes involved in sensing and biosynthesis of cholesterol, such as Sterol Regulatory Element Binding Transcription Factor 2 (SREBF2) and SREBP cleavage activating protein (SCAP) which are required for SARS-CoV-2 infection (170). This finding agrees with Hoffmann et al., who performed a focused high-coverage CRISPR-Cas9 library targeting 332 host proteins identified as high-confidence SARS-CoV-2 protein interactors (175). Interestingly, Wang et al. also identified clusters linked to cholesterol metabolism (low-density lipoprotein receptor (LDLR), NPC1, SCAP, and SREBF2) as a critical host pathway through a genome-wide CRISPR screen in SARS-CoV-2-infected cells (176). The SREBP family of transcription factor control cholesterol and lipid metabolism (177). The treatment with SREBP pathway modulators such as PF-429242, 25-HC, and Fatostatin reduces the SARS-CoV-2 replication and entry, suggesting that cellular cholesterol is required (176). Also, amlodipine, a calcium-channel antagonist, increases cholesterol levels and blocks SARS-CoV-2 infection (71). This finding is consistent with the Zhang et al. study, where amlodipine and other calcium channel inhibitors blocked the post-entry replication events of SARS-CoV-2 in vitro (178). Zhang et al. associated the amlodipine therapy with a decreased case fatality rate in COVID-19 patients (178). Also, a cholesterol accumulation by treating 25-HC and NPC1 inhibitors itraconazole (ICZ) and $\mathrm{U} 18666 \mathrm{~A}$ restricts SARS-CoV-2 replication (85).

Some FDA-approved cholesterol-lowering drugs have antiviral properties and are safe for use in humans, which reduces the time and requirements for their study in clinical trials (179). In this regard, statins and metformin are promising candidates for the treatment of infections caused by enveloped viruses, such as Dengue virus (DENV), Zika virus (ZIKV), hepatitis $\mathrm{C}$ virus (HCV), Japanese encephalitis virus (JEV), influenza A virus (IAV), and recently for the treatment of SARS-CoV-2 (180-184). These drugs interfere in different metabolic pathways for lipid synthesis by inhibiting critical cholesterol and fatty acid synthesis (185).

Statins directly inhibit the HMGCR enzyme, responsible for de novo cholesterol synthesis inducing alteration of cholesterolrich lipid rafts (Figure 2) $(186,187)$ and, by a consequence, inhibits infection caused by coronaviruses (41). Interestingly, the use of statins is associated with a lower risk of mortality among people with COVID-19 $(188,189)$; however, its use to treat these diseases remains controversial (190-192). Although the antiviral mechanism of statins is unknown, it could affect viral replication and morphogenesis, as occurs with other viruses (193-196). Furthermore, the immunomodulatory properties of statins are another advantage for treating viral diseases, such as those caused by influenza and Ebola viruses (182, 197, 198).

Metformin is another drug with lipid-lowering effects that have gained interest in recent decades due to its pleiotropic effects and antiviral properties (199). Metformin inhibits cholesterol and fatty acid synthesis by activating the AMPactivated protein kinase (AMPK), involved in multiple energetic pathways in the cell (200). Similar to statins, its lipidlowering effect, coupled with the immunomodulatory effects of Metformin, could be responsible for the benefits reported in COVID-19 patients with type 2 diabetes and insulin resistance (201-203). Thus, the use of Metformin could benefit the survival of older adults infected by SARS-CoV-2 compared to those who do not take this drug (204-206). Metformin could increase the endosomal and lysosomal $\mathrm{pH}$ values. Acting directly on two crucial membrane compartments found in cholesterol-rich lipid rafts to maintain and regulate the endosomal acidic $\mathrm{pH}$ (Figure 2): (1) using the Vacuolar ATPase (V-ATPase) as a proton-pumping or acidifier compartment; (2) following the endosomal $\mathrm{Na}+/ \mathrm{H}+$ exchangers (eNHEs), as proton leaking or alkalizing compartment on the endosomal membrane (143). These mechanisms lead to the inhibition of viral infection through increasing the cellular $\mathrm{pH}$ and subsequently interfering with the endocytic cycle $(143,145,146)$. In addition, metformin and the fatty acid synthase (FASN) inhibitor orlistat can inhibit coronavirus replication and reduce systemic inflammation to restore immune homeostasis (165).

SARS-CoV-2 entry depends on binding to ACE2 localizes to both monosialotetrahexosylganglioside1 (GM1) lipid rafts and PIP2 domains embedded in cholesterol-rich lipid rafts (141). Drugs such as HC directly perturb ordered GM1 (142), inhibiting viral entry by alteration of the cholesterol-rich lipid rafts where the SARS-CoV-2 receptors are located (Figure 2) $(142,144)$. Another effect is the capability to negatively alter endocytosis, maturation of endosomes, and transport virions (Figure 2) (144). Moreover, cholesterol depletion of membranes with $M \beta C D$ reduces the SARS-CoV-2 infection (59). All these reports confirm the role of cholesterol-rich lipid rafts as therapeutic targets for COVID-19.

At present, there is no scientific evidence that treatment with these drugs can worsen covid-19 disease; on the contrary, it may improve the outcome of SARS-COV2-infected patients (Table 2). Therefore, the risk of their use is limited to the side effects already known for each drug (Table 2) (188, 189, 204208). Regarding statins, some of the side effects increased the incidence of diabetes and cataracts and frequent muscular side effects $(209,210)$. In the case of metformin, the main side effect is lactic acidosis (211). It should be noted that their use as antivirals suggests an acute and short-term treatment, reducing the side effects associated with long periods of treatment (209, 211-213). Preclinical studies are necessary to evaluate its safety during viral infections, as currently metformin is evaluated during ZIKV infections $(184,214,215)$.

On the other hand, empirical evidence for HCQ effectiveness in COVID-19 is limited. Currently, a few studies reported the antiviral activity of HCQ against SARS-CoV-2 $(144,216)$. Following the promising results, the usage of HCQ for certain COVID-19 patients improve. However, HCQ is well known to have severe complications and side effects in some cases. Reports raise concerns that SARS-CoV-2 causes liver and renal 
TABLE 2 | Anti-SARS-CoV-2 activity of FDA-approved cholesterol-lowering drugs.

\begin{tabular}{|c|c|c|c|}
\hline $\begin{array}{l}\text { Lipid-lowering } \\
\text { Drug }\end{array}$ & Study type & Effect & References \\
\hline $\begin{array}{l}\text { ATV, RSV, } \\
\text { SIM, PRV, FLV } \\
\text { and PTV }\end{array}$ & $\begin{array}{l}\text { Retrospective study: } \\
\text { a. } 13,981 \text { patients diagnosed with SARS-Cov-2 in Hubei Province, } \\
\text { China } \\
\text { b. } 2921 \text { patients diagnosed with SARS-Cov-2, who are hospitalized } \\
\text { in } 150 \text { Spanish hospitals. }\end{array}$ & Reduced risk of mortality among people with COVID-19 & $(188,189)$ \\
\hline MET & $\begin{array}{l}\text { Retrospective studies: } \\
\text { a. } 283 \text { diabetic patients hospitalized with confirmed SARS-Cov-2 in } \\
\text { the Tongji Hospital of Wuhan, China. } \\
\text { b. } 1139 \text { patients positive SARS-Cov- } 2 \text { in } 8 \text { states in USA. } \\
\text { c. } 775 \text { nursing Home Residents Infected with SARS-CoV2 from the } \\
\text { Community Living Centers (CLC), USA. }\end{array}$ & $\begin{array}{l}\text { a. Antidiabetic treatment with metformin was associated with } \\
\text { lower hospitalization and mortality. } \\
\text { b. Relative survival benefit in nursing home residents on } \\
\text { metformin. }\end{array}$ & $(204-206)$ \\
\hline $\mathrm{CQ} / \mathrm{HCQ}$ & $\begin{array}{l}\text { Clinical study: } \\
\text { a. Treating group of } 100 \text { COVID-19 patients treated with CQ. } \\
\text { b. } 36 \text { patients diagnosed with SARS-Cov-2. Treatment group ( } 20 \\
\text { patients) received HCQ } 200 \mathrm{mg} \text { for ten days, three times a day } \\
\text { ( } 600 \mathrm{mg} \text { daily). Control group ( } 16 \text { patients). Six patients received } \\
\text { AZI to prevent bacterial infections. }\end{array}$ & $\begin{array}{l}\text { a. Improvements of pneumonia and lung imaging and reduction } \\
\text { of the duration of illness without any adverse effects. } \\
\text { b. On day six, treatment group showed a significant reduction in } \\
\text { the viral load. The six patients who received a combination } \\
\text { (HCQ and AZI) were testing negative, indicates the high } \\
\text { effectiveness of the combination. }\end{array}$ & $(207,208)$ \\
\hline
\end{tabular}

SARS-CoV-2, severe acute respiratory syndrome coronavirus; STAs, Statins; ATV, Atorvastatin; RSV, Rosuvastatin; SIM, Simvastatin; PRV, Pravastatin; FLV, Fluvastatin; PTV, Pitavastatin; MET, Metformin; HCQ, Hydroxychloroquine; AZI, Azithromycin; CQ, Chloroquine.

impairment, and using HCQ for COVID-19 treatment might increase the risk of toxicity (217). Despite these, clinical trials currently investigate the effectiveness of HCQ in treating COVID-19 (218) because it confers antiviral and antiinflammatory effects with fewer side effects. However, proper randomized controlled trials of HCQ and individual immune profiles of COVID-19 patients are needed and should be thoroughly evaluated and considered (144).

\section{CONCLUDING REMARKS}

It is well known that coronaviruses interact with a large and diverse repertoire of receptors located on lipid rafts, which are regions on the membrane that provide a platform that concentrates receptors that serve as an entry portal into the cell. This review focuses on the role of cholesterol-rich lipid rafts as a platform for SARS-CoV-2 entry. Cholesterol is vital in the SARSCoV-2 entry and pathogenesis. Several reports demonstrated that deprivation of cellular cholesterol significantly affects SARS-CoV2 attachment and internalization due to a redistribution of receptors and co-receptors found in the cholesterol-rich lipids rafts, which would attenuate COVID-19 symptoms. Therefore,

\section{REFERENCES}

1. Pan A, Liu L, Wang C, Guo H, Hao X, Wang Q, et al. Association of Public Health Interventions With the Epidemiology of the COVID-19 Outbreak in Wuhan, China. JAMA (2020) 323:1915-23. doi: 10.1001/jama.2020.6130

2. Huang C, Wang Y, Li X, Ren L, Zhao J, Hu Y, et al. Clinical Features of Patients Infected With 2019 Novel Coronavirus in Wuhan, China. Lancet (2020) 395:497-506. doi: 10.1016/S0140-6736(20)30183-5

3. Lu R, Zhao X, Li J, Niu P, Yang B, Wu H, et al. Genomic Characterisation and Epidemiology of 2019 Novel Coronavirus: Implications for Virus deciphering the SARS-CoV-2 receptors in cholesterol-rich lipid rafts is vital for developing antiviral strategies that inhibit viral replication.

\section{AUTHOR CONTRIBUTIONS}

All authors included in the manuscript have made substantial contributions to the work. Under the supervision of JR-R, SP-R, RÁ, and VB-D. JR-R, and SP-R: conceptualization. JR-R, SP-R, $\mathrm{CC}, \mathrm{CF}$, and LJ-G: investigation and writing-original draft. JR-R, SP-R, VB-D, RÁ, AM-P, and GM-M: formal analysis. JR-R, SP-R, JO-R, GM-M, JQ-G, AM-P, VB-D, and RÁ: writing-review and editing. All authors contributed to the article and approved the submitted version.

\section{FUNDING}

This research was supported by CONACYT (Mexico), grants: Pronaii 302979 and A1-S-9005 from RA. CF, CC, JO-R, LJ-G, and SP-R had a scholarship granted by CONACYT during the writing of this review.
Origins and Receptor Binding. Lancet (2020) 395:565-74. doi: 10.1016/ S0140-6736(20)30251-8

4. Kim D, Lee J-Y, Yang J-S, Kim JW, Kim VN, Chang H. The Architecture of SARSCoV-2 Transcriptome. Cell (2020) 181:914-21.e10. doi: 10.1016/..cell.2020.04.011

5. Wang M-Y, Zhao R, Gao L-J, Gao X-F, Wang D-P, Cao J-M. SARS-CoV-2: Structure, Biology, and Structure-Based Therapeutics Development. Front Cell Infect Microbiol (2020) 10:587269. doi: 10.3389/fcimb.2020.587269

6. Dasgupta C, Zhang L. Angiotensin II Receptors and Drug Discovery in Cardiovascular Disease. Drug Discovery Today (2011) 16:22-34. doi: 10.1016/j.drudis.2010.11.016 
7. Salamanna F, Maglio M, Landini MP, Fini M. Body Localization of ACE-2: On the Trail of the Keyhole of SARS-CoV-2. Front Med (2020) 7:594495. doi: 10.3389/fmed.2020.594495

8. Bian J, Li Z. Angiotensin-Converting Enzyme 2 (ACE2): SARS-CoV-2 Receptor and RAS Modulator. Acta Pharm Sin B (2021) 11:1-12. doi: $10.1016 /$ j.apsb.2020.10.006

9. Choudhury A, Mukherjee S. In Silico Studies on the Comparative Characterization of the Interactions of SARS-CoV-2 Spike Glycoprotein With ACE-2 Receptor Homologs and Human TLRs. J Med Virol (2020) 92 (10):2105-13. doi: 10.1002/jmv.25987. 10.1002/jmv.25987.

10. Clausen TM, Sandoval DR, Spliid CB, Pihl J, Painter CD, Thacker BE, et al. SARS-CoV-2 Infection Depends on Cellular Heparan Sulfate and ACE2. Cell (2020) 183(4):1043-57. doi: 10.1101/2020.07.14.201616

11. Wang K, Chen W, Zhang Z, Deng Y, Lian J-Q, Du P, et al. CD147-Spike Protein Is a Novel Route for SARS-CoV-2 Infection to Host Cells. Signal Transduct Target Ther (2020) 5:283. doi: 10.1038/s41392-020-00426-x

12. Wei C, Wan L, Yan Q, Wang X, Zhang J, Yang X, et al. HDL-Scavenger Receptor B Type 1 Facilitates SARS-CoV-2 Entry. Nat Metab (2020) 2:1391400. doi: 10.1038/s42255-020-00324-0

13. Zang R, Gomez Castro MF, McCune BT, Zeng Q, Rothlauf PW, Sonnek NM, et al. TMPRSS2 and TMPRSS4 Promote SARS-CoV-2 Infection of Human Small Intestinal Enterocytes. Sci Immunol (2020) 5:eabc3582. doi: 10.1126/ sciimmunol.abc3582

14. Bohan D, Ert HV, Ruggio N, Rogers KJ, Badreddine M, Aguilar Briseño JA, et al. Phosphatidylserine Receptors Enhance SARS-CoV-2 Infection: AXL as a Therapeutic Target for COVID-19. J Immunol (2021) 206:20.38. doi: 10.1101/2021.06.15.448419

15. Hudák A, Letoha A, Szilák L, Letoha T. Contribution of Syndecans to the Cellular Entry of SARS-CoV-2. Int J Mol Sci (2021) 22:5336. doi: 10.3390/ ijms22105336

16. Kondo Y, Larabee JL, Gao L, Shi H, Shao B, Hoover CM, et al. L-SIGN Is a Receptor on Liver Sinusoidal Endothelial Cells for SARS-CoV-2 Virus. JCI Insight (2021) 6:e148999. doi: 10.1172/jci.insight.148999

17. Wang S, Qiu Z, Hou Y, Deng X, Xu W, Zheng T, et al. AXL Is a Candidate Receptor for SARS-CoV-2 That Promotes Infection of Pulmonary and Bronchial Epithelial Cells. Cell Res (2021) 31(2):1-15. doi: 10.1038/s41422020-00460-y

18. Brown DA, London E. Structure and Function of Sphingolipid- and Cholesterol-Rich Membrane Rafts *. J Biol Chem (2000) 275:17221-4. doi: $10.1074 /$ jbc.R000005200

19. Nichols B. Caveosomes and Endocytosis of Lipid Rafts. J Cell Sci (2003) 116:4707-14. doi: $10.1242 /$ jcs.00840

20. Pike LJ. Lipid Rafts: Bringing Order to Chaos. J Lipid Res (2003) 44:655-67. doi: 10.1194/jlr.R200021-JLR200

21. Ouweneel AB, Thomas MJ, Sorci-Thomas MG. The Ins and Outs of Lipid Rafts: Functions in Intracellular Cholesterol Homeostasis, Microparticles, and Cell Membranes. J Lipid Res (2020) 61:676-86. doi: 10.1194/ jlr.TR119000383

22. van IJzendoorn SCD, Agnetti J, Gassama-Diagne A. Mechanisms Behind the Polarized Distribution of Lipids in Epithelial Cells. Biochim Biophys Acta Biomembr (2020) 1862:183145. doi: 10.1016/j.bbamem.2019.183145

23. Varshney P, Yadav V, Saini N. Lipid Rafts in Immune Signalling: Current Progress and Future Perspective. Immunology (2016) 149:13-24. doi: 10.1111/imm.12617

24. Bukrinsky MI, Mukhamedova N, Sviridov ,D. Lipid Rafts and Pathogens: The Art of Deception and Exploitation. J Lipid Res (2020) 61:601-10. doi: 10.1194/jlr.TR119000391

25. Khanmohammadi S, Rezaei N. Role of Toll-Like Receptors in the Pathogenesis of COVID-19. J Med Virol (2021) 93(5):2735-9. doi: $10.1002 / j m v .26826$

26. Osuna-Ramos JF, Reyes-Ruiz JM, del Ángel RM. The Role of Host Cholesterol During Flavivirus Infection. Front Cell Infect Microbiol (2018) 8:388. doi: $10.3389 /$ fcimb. 2018.00388

27. Fecchi K, Anticoli S, Peruzzu D, Iessi E, Gagliardi MC, Matarrese P, et al. Coronavirus Interplay With Lipid Rafts and Autophagy Unveils Promising Therapeutic Targets. Front Microbiol (2020) 11:1821. doi: 10.3389/ fmicb.2020.01821
28. Wang Y, Zhang Y, Zhang C, Hu M, Yan Q, Zhao H, et al. Cholesterol-Rich Lipid Rafts in the Cellular Membrane Play an Essential Role in Avian Reovirus Replication. Front Microbiol (2020) 11:597794. doi: 10.3389/ fmicb.2020.597794

29. Bieberich E. Sphingolipids and Lipid Rafts: Novel Concepts and Methods of Analysis. Chem Phys Lipids (2018) 216:114-31. doi: 10.1016/j.chemphyslip. 2018.08.003

30. Sviridov D, Miller YI, Ballout RA, Remaley AT, Bukrinsky M. Targeting Lipid Rafts-A Potential Therapy for COVID-19. Front Immunol (2020) 11:574508. doi: 10.3389/fimmu.2020.574508

31. Ripa I, Andreu S, López-Guerrero JA, Bello-Morales R. Membrane Rafts: Portals for Viral Entry. Front Microbiol (2021) 12:631274. doi: 10.3389/ fmicb.2021.631274

32. Sanders DW, Jumper CC, Ackerman PJ, Bracha D, Donlic A, Kim H, et al. SARS-CoV-2 Requires Cholesterol for Viral Entry and Pathological Syncytia Formation. Elife (2021) 10:e65962. doi: 10.7554/eLife.65962

33. Mañes S, del Real G, Martínez-A C. Pathogens: Raft Hijackers. Nat Rev Immunol (2003) 3:557-68. doi: 10.1038/nri1129

34. Levental I, Levental K, Heberle F. Lipid Rafts: Controversies Resolved, Mysteries Remain. Trends Cell Biol (2020) 30:341-53. doi: 10.1016/ j.tcb.2020.01.009

35. Chen B, Tian E-K, He B, Tian L, Han R, Wang S, et al. Overview of Lethal Human Coronaviruses. Sig Transduct Target Ther (2020) 5:1-16. doi: 10.1038/s41392-020-0190-2

36. Dijkman R, Jebbink MF, Koekkoek SM, Deijs M, Jónsdóttir HR, Molenkamp $\mathrm{R}$, et al. Isolation and Characterization of Current Human Coronavirus Strains in Primary Human Epithelial Cell Cultures Reveal Differences in Target Cell Tropism. J Virol (2013) 87:6081-90. doi: 10.1128/JVI.03368-12

37. Liang Y, Wang M-L, Chien C-S, Yarmishyn AA, Yang Y-P, Lai W-Y, et al. Highlight of Immune Pathogenic Response and Hematopathologic Effect in SARS-CoV, MERS-CoV, and SARS-Cov-2 Infection. Front Immunol (2020) 11:1022. doi: 10.3389/fimmu.2020.01022

38. Nomura R, Kiyota A, Suzaki E, Kataoka K, Ohe Y, Miyamoto K, et al. Human Coronavirus 229e Binds to CD13 in Rafts and Enters the Cell Through Caveolae. J Virol (2004) 78:8701-8. doi: 10.1128/JVI.78.16.87018708.2004

39. Choi KS, Aizaki H, Lai MMC. Murine Coronavirus Requires Lipid Rafts for Virus Entry and Cell-Cell Fusion But Not for Virus Release. J Virol (2005) 79:9862-71. doi: 10.1128/JVI.79.15.9862-9871.2005

40. Pratelli A, Colao V. Role of the Lipid Rafts in the Life Cycle of Canine Coronavirus. J Gen Virol (2015) 96:331-7. doi: 10.1099/vir.0.070870-0

41. Guo H, Huang M, Yuan Q, Wei Y, Gao Y, Mao L, et al. The Important Role of Lipid Raft-Mediated Attachment in the Infection of Cultured Cells by Coronavirus Infectious Bronchitis Virus Beaudette Strain. PloS One (2017) 12:e0170123. doi: 10.1371/journal.pone.0170123

42. Glende J, Schwegmann-Wessels C, Al-Falah M, Pfefferle S, Qu X, Deng H, et al. Importance of Cholesterol-Rich Membrane Microdomains in the Interaction of the S Protein of SARS-Coronavirus With the Cellular Receptor Angiotensin-Converting Enzyme 2. Virology (2008) 381:215-21. doi: 10.1016/j.virol.2008.08.026

43. Li G-M, Li Y-G, Yamate M, Li S-M, Ikuta K. Lipid Rafts Play an Important Role in the Early Stage of Severe Acute Respiratory Syndrome-Coronavirus Life Cycle. Microbes Infect (2007) 9:96-102. doi: 10.1016/j.micinf. 2006.10.015

44. Gorkhali R, Koirala P, Rijal S, Mainali A, Baral A, Bhattarai HK. Structure and Function of Major SARS-CoV-2 and SARS-CoV Proteins. Bioinform Biol Insights (2021) 15:11779322211025876. doi: 10.1177/11779322211025876

45. Liao Y, Yuan Q, Torres J, Tam JP, Liu DX. Biochemical and Functional Characterization of the Membrane Association and Membrane Permeabilizing Activity of the Severe Acute Respiratory Syndrome Coronavirus Envelope Protein. Virology (2006) 349:264-75. doi: 10.1016/ j.virol.2006.01.028

46. Nieto-Torres JL, DeDiego ML, Verdiá-Báguena C, Jimenez-Guardeño JM, Regla-Nava JA, Fernandez-Delgado R, et al. Severe Acute Respiratory Syndrome Coronavirus Envelope Protein Ion Channel Activity Promotes Virus Fitness and Pathogenesis. PloS Pathog (2014) 10:e1004077. doi: 10.1371/journal.ppat.1004077 
47. Sarkar M, Saha S. Structural Insight Into the Role of Novel SARS-CoV-2 E Protein: A Potential Target for Vaccine Development and Other Therapeutic Strategies. PloS One (2020) 15:e0237300. doi: 10.1371/journal.pone.0237300

48. Lu Y, Liu DX, Tam JP. Lipid Rafts Are Involved in SARS-CoV Entry Into Vero E6 Cells. Biochem Biophys Res Commun (2008) 369:344-9. doi: 10.1016/j.bbrc.2008.02.023

49. V'kovski P, Kratzel A, Steiner S, Stalder H, Thiel V. Coronavirus Biology and Replication: Implications for SARS-CoV-2. Nat Rev Microbiol (2021) 19:155-70. doi: 10.1038/s41579-020-00468-6

50. Gadanec LK, McSweeney KR, Qaradakhi T, Ali B, Zulli A, Apostolopoulos V. Can SARS-CoV-2 Virus Use Multiple Receptors to Enter Host Cells? Int J Mol Sci (2021) 22:992. doi: 10.3390/ijms22030992

51. Lan J, Ge J, Yu J, Shan S, Zhou H, Fan S, et al. Structure of the SARS-CoV-2 Spike Receptor-Binding Domain Bound to the ACE2 Receptor. Nature (2020) 581:215-20. doi: 10.1038/s41586-020-2180-5

52. Wan Y, Shang J, Graham R, Baric RS, Li F. Receptor Recognition by the Novel Coronavirus From Wuhan: An Analysis Based on Decade-Long Structural Studies of SARS Coronavirus. J Virol (2020) 94:e00127-20. doi: 10.1128/JVI.00127-20

53. Cantuti-Castelvetri L, Ojha R, Pedro LD, Djannatian M, Franz J, Kuivanen S, et al. Neuropilin-1 Facilitates SARS-CoV-2 Cell Entry and Infectivity. Science (2020) 370:856-60. doi: 10.1126/science.abd2985

54. Duan L, Zheng Q, Zhang H, Niu Y, Lou Y, Wang H. The SARS-CoV-2 Spike Glycoprotein Biosynthesis, Structure, Function, and Antigenicity: Implications for the Design of Spike-Based Vaccine Immunogens. Front Immunol (2020) 11:576622. doi: 10.3389/fimmu.2020.576622

55. Walls AC, Park Y-J, Tortorici MA, Wall A, McGuire AT, Veesler D. Structure, Function, and Antigenicity of the SARS-CoV-2 Spike Glycoprotein. Cell (2020) 181:281-92.e6. doi: 10.1016/j.cell.2020.02.058

56. Wrapp D, Wang N, Corbett KS, Goldsmith JA, Hsieh C-L, Abiona O, et al. Cryo-EM Structure of the 2019-Ncov Spike in the Prefusion Conformation. Science (2020) 367:1260-3. doi: 10.1126/science.abb2507

57. Fantini J, Di Scala C, Chahinian H, Yahi N. Structural and Molecular Modelling Studies Reveal a New Mechanism of Action of Chloroquine and Hydroxychloroquine Against SARS-CoV-2 Infection. Int J Antimicrobial Agents (2020) 55:105960. doi: 10.1016/j.ijantimicag.2020.105960

58. Bayati A, Kumar R, Francis V, McPherson PS. SARS-CoV-2 Infects Cells After Viral Entry via Clathrin-Mediated Endocytosis. J Biol Chem (2021) 296:1-12. doi: 10.1016/j.jbc.2021.100306

59. Li X, Zhu W, Fan M, Zhang J, Peng Y, Huang F, et al. Dependence of SARSCoV-2 Infection on Cholesterol-Rich Lipid Raft and Endosomal Acidification. Comput Struct Biotechnol J (2021) 19:1933-43. doi: 10.1016/ j.csbj.2021.04.001

60. Cai Y, Zhang J, Xiao T, Peng H, Sterling SM, Walsh RM, et al. Distinct Conformational States of SARS-CoV-2 Spike Protein. Science (2020) 369:1586-92. doi: 10.1126/science.abd4251

61. Lu M, Uchil PD, Li W, Zheng D, Terry DS, Gorman J, et al. Real-Time Conformational Dynamics of SARS-CoV-2 Spikes on Virus Particles. Cell Host Microbe (2020) 28:880-91.e8. doi: 10.1016/j.chom.2020.11.001

62. Ferreira APA, Boucrot E. Mechanisms of Carrier Formation During Clathrin-Independent Endocytosis. Trends Cell Biol (2018) 28:188-200. doi: 10.1016/j.tcb.2017.11.004

63. Renard H-F, Boucrot E. Unconventional Endocytic Mechanisms. Curr Opin Cell Biol (2021) 71:120-9. doi: 10.1016/j.ceb.2021.03.001

64. Hoffmann M, Kleine-Weber H, Schroeder S, Krüger N, Herrler T, Erichsen S, et al. SARS-CoV-2 Cell Entry Depends on ACE2 and TMPRSS2 and Is Blocked by a Clinically Proven Protease Inhibitor. Cell (2020) 181:271-80.e8. doi: 10.1016/j.cell.2020.02.052

65. Zhu Y, Feng F, Hu G, Wang Y, Yu Y, Zhu Y, et al. A Genome-Wide CRISPR Screen Identifies Host Factors That Regulate SARS-CoV-2 Entry. Nat Commun (2021) 12:961. doi: 10.1038/s41467-021-21213-4

66. Ou T, Mou H, Zhang L, Ojha A, Choe H, Farzan M. HydroxychloroquineMediated Inhibition of SARS-CoV-2 Entry Is Attenuated by TMPRSS2. PloS Pathog (2021) 17:e1009212. doi: 10.1371/journal.ppat.1009212

67. Ballout RA, Sviridov D, Bukrinsky MI, Remaley AT. The Lysosome: A Potential Juncture Between SARS-CoV-2 Infectivity and Niemann-Pick Disease Type C, With Therapeutic Implications. FASEB J (2020) 34:725364. doi: 10.1096/fj.202000654R
68. García-Dorival I, Cuesta-Geijo MÁ., Barrado-Gil L, Galindo I, Garaigorta U, Urquiza J, et al. Identification of Niemann-Pick C1 Protein as a Potential Novel SARS-CoV-2 Intracellular Target. Antiviral Res (2021) 194:105167. doi: 10.1016/j.antiviral.2021.105167

69. Carette JE, Raaben M, Wong AC, Herbert AS, Obernosterer G, Mulherkar N, et al. Ebola Virus Entry Requires the Cholesterol Transporter Niemann-Pick C1. Nature (2011) 477:340-3. doi: 10.1038/nature10348

70. Lasala F, García-Rubia A, Requena C, Galindo I, Cuesta-Geijo MA, GarcíaDorival I, et al. Identification of Potential Inhibitors of Protein-Protein Interaction Useful to Fight Against Ebola and Other Highly Pathogenic Viruses. Antiviral Res (2021) 186:105011. doi: 10.1016/j.antiviral. 2021.105011

71. Daniloski Z, Jordan TX, Wessels H-H, Hoagland DA, Kasela S, Legut M, et al. Identification of Required Host Factors for SARS-CoV-2 Infection in Human Cells. Cell (2021) 184:92-105.e16. doi: 10.1016/j.cell.2020.10.030

72. Sturley SL, Rajakumar T, Hammond N, Higaki K, Márka Z, Márka S, et al. Potential COVID-19 Therapeutics From a Rare Disease: Weaponizing Lipid Dysregulation to Combat Viral Infectivity. J Lipid Res (2020) 61:972-82. doi: 10.1194/jlr.R120000851

73. Gordon DE, Jang GM, Bouhaddou M, Xu J, Obernier K, White KM, et al. A SARS-CoV-2 Protein Interaction Map Reveals Targets for Drug Repurposing. Nature (2020) 583:459-68. doi: 10.1038/s41586-020-2286-9

74. Wang Q, Wu J, Wang H, Gao Y, Liu Q, Mu A, et al. Structural Basis for RNA Replication by the SARS-CoV-2 Polymerase. Cell (2020) 182:417-28.e13. doi: 10.1016/j.cell.2020.05.034

75. Jin K, Wen Z, Wu B, Zhang H, Qiu J, Wang Y, et al. NOTCH-Induced Rerouting of Endosomal Trafficking Disables Regulatory $\mathrm{T}$ Cells in Vasculitis. J Clin Invest (2021) 131:1-20. doi: 10.1172/JCI136042

76. Reyes-Ruiz JM, Osuna-Ramos JF, De Jesús-González LA, Palacios-Rápalo $\mathrm{SN}$, Cordero-Rivera CD, Farfan-Morales $\mathrm{CN}$, et al. The Regulation of Flavivirus Infection by Hijacking Exosome-Mediated Cell-Cell Communication: New Insights on Virus-Host Interactions. Viruses (2020) 12:765. doi: 10.3390/v12070765

77. Barberis E, Vanella VV, Falasca M, Caneapero V, Cappellano G, Raineri D, et al. Circulating Exosomes Are Strongly Involved in SARS-CoV-2 Infection. Front Mol Biosci (2021) 8:632290. doi: 10.3389/fmolb.2021.632290

78. Sobo K, Chevallier J, Parton RG, Gruenberg J, van der Goot FG. Diversity of Raft-Like Domains in Late Endosomes. PloS One (2007) 2:e391. doi: 10.1371/journal.pone.0000391

79. Lingwood D, Simons K. Lipid Rafts As a Membrane-Organizing Principle. Science (2010) 327:46-50. doi: 10.1126/science.1174621

80. Sezgin E, Levental I, Mayor S, Eggeling C. The Mystery of Membrane Organization: Composition, Regulation and Roles of Lipid Rafts. Nat Rev Mol Cell Biol (2017) 18:361-74. doi: 10.1038/nrm.2017.16

81. Luquain-Costaz C, Rabia M, Hullin-Matsuda F, Delton I. Bis (monoacylglycero)Phosphate, an Important Actor in the Host Endocytic Machinery Hijacked by SARS-CoV-2 and Related Viruses. Biochimie (2020) 179:247-56. doi: 10.1016/j.biochi.2020.10.018

82. Luquain-Costaz C, Lefai E, Arnal-Levron M, Markina D, Sakaï S, Euthine V, et al. Bis(Monoacylglycero)Phosphate Accumulation in Macrophages Induces Intracellular Cholesterol Redistribution, Attenuates Liver-X Receptor/ATP-Binding Cassette Transporter A1/ATP-Binding Cassette Transporter G1 Pathway, and Impairs Cholesterol Efflux. Arteriosclerosis Thromb Vasc Biol (2013) 33:1803-11. doi: 10.1161/ATVBAHA.113.301857

83. Chai AB, Ammit AJ, Gelissen IC. Examining the Role of ABC Lipid Transporters in Pulmonary Lipid Homeostasis and Inflammation. Respir Res (2017) 18:1-9. doi: 10.1186/s12931-017-0526-9

84. Arnal-Levron M, Chen Y, Greimel P, Calevro F, Gaget K, Riols F, et al. Bis (monoacylglycero)Phosphate Regulates Oxysterol Binding Protein-Related Protein 11 Dependent Sterol Trafficking. Biochim Biophys Acta (BBA) - Mol Cell Biol Lipids (2019) 1864:1247-57. doi: 10.1016/j.bbalip.2019.05.011

85. Zang R, Case JB, Yutuc E, Ma X, Shen S, Castro MFG, et al. Cholesterol 25Hydroxylase Suppresses SARS-CoV-2 Replication by Blocking Membrane Fusion. PNAS (2020) 117:32105-13. doi: 10.1073/pnas.2012197117

86. Adams CM, Reitz J, De Brabander JK, Feramisco JD, Li L, Brown MS, et al. Cholesterol and 25-Hydroxycholesterol Inhibit Activation of SREBPs by Different Mechanisms, Both Involving SCAP and Insigs*. J Biol Chem (2004) 279:52772-80. doi: 10.1074/jbc.M410302200 
87. Zu S, Deng Y-Q, Zhou C, Li J, Li L, Chen Q, et al. 25-Hydroxycholesterol Is a Potent SARS-CoV-2 Inhibitor. Cell Res (2020) 30:1043-5. doi: 10.1038/ s41422-020-00398-1

88. Marcello A, Civra A, Milan Bonotto R, Nascimento Alves L, Rajasekharan S, Giacobone C, et al. The Cholesterol Metabolite 27-Hydroxycholesterol Inhibits SARS-CoV-2 and Is Markedly Decreased in COVID-19 Patients. Redox Biol (2020) 36:101682. doi: 10.1016/j.redox.2020.101682

89. Hering H, Lin C-C, Sheng M. Lipid Rafts in the Maintenance of Synapses, Dendritic Spines, and Surface AMPA Receptor Stability. J Neurosci (2003) 23:3262-71. doi: 10.1523/JNEUROSCI.23-08-03262.2003

90. Pike LJ, Han X, Gross RW. EGF Receptors Are Localized to Lipid Rafts That Contain a Balance of Inner and Outer Leaflet Lipids: A Shotgun Lipidomics Study. J Biol Chem (2005) 280:26796-804. doi: 10.1074/jbc.M503805200

91. Roh S-E, Hong YH, Jang DC, Kim J, Kim SJ. Lipid Rafts Serve as Signaling Platforms for Mglul Receptor-Mediated Calcium Signaling in Association With Caveolin. Mol Brain (2014) 7:9. doi: 10.1186/1756-6606-7-9

92. Zabroski IO, Nugent MA. Lipid Raft Association Stabilizes VEGF Receptor 2 in Endothelial Cells. Int J Mol Sci (2021) 22:798. doi: 10.3390/ijms22020798

93. Simons K, Gerl MJ. Revitalizing Membrane Rafts: New Tools and Insights. Nat Rev Mol Cell Biol (2010) 11:688-99. doi: 10.1038/nrm2977

94. Chazal N, Gerlier D. Virus Entry, Assembly, Budding, and Membrane Rafts. Microbiol Mol Biol Rev (2003) 67:226-37. doi: 10.1128/MMBR.67.2.226237.2003

95. Antalis TM, Buzza MS. Extracellular: Plasma Membrane Proteases - Serine Proteases. Encycl Cell Biol (2016) 1:650-60. doi: 10.1016/B978-0-12-3944474.10076-8

96. Farrugia BL, Lord MS, Melrose J, Whitelock JM. The Role of Heparan Sulfate in Inflammation, and the Development of Biomimetics as AntiInflammatory Strategies. J Histochem Cytochem (2018) 66:321-36. doi: 10.1369/0022155417740881

97. Meneghetti MCZ, Hughes AJ, Rudd TR, Nader HB, Powell AK, Yates EA, et al. Heparan Sulfate and Heparin Interactions With Proteins. J R Soc Interface (2015) 12:20150589. doi: 10.1098/rsif.2015.0589

98. Woods A. Syndecans: Transmembrane Modulators of Adhesion and Matrix Assembly. J Clin Invest (2001) 107:935-41. doi: 10.1172/JCI12802

99. Gugliandolo A, Chiricosta L, Calcaterra V, Biasin M, Cappelletti G, Carelli S, et al. SARS-CoV-2 Infected Pediatric Cerebral Cortical Neurons: Transcriptomic Analysis and Potential Role of Toll-Like Receptors in Pathogenesis. Int J Mol Sci (2021) 22:8059. doi: 10.3390/ijms22158059

100. Molteni M, Gemma S, Rossetti C. The Role of Toll-Like Receptor 4 in Infectious and Noninfectious Inflammation. Mediators Inflammation (2016) 2016:6978936. doi: 10.1155/2016/6978936

101. Płóciennikowska A, Hromada-Judycka A, Borzęcka K, Kwiatkowska K. CoOperation of TLR4 and Raft Proteins in LPS-Induced Pro-Inflammatory Signaling. Cell Mol Life Sci (2015) 72:557-81. doi: 10.1007/s00018-014-1762-5

102. Shirato K, Kizaki T. SARS-CoV-2 Spike Protein S1 Subunit Induces ProInflammatory Responses via Toll-Like Receptor 4 Signaling in Murine and Human Macrophages. Heliyon (2021) 7:e06187. doi: 10.1016/j.heliyon. 2021.e06187

103. Lee C-L, Lam MPY, Lam KKW, Leung CON, Pang RTK, Chu IK, et al. Identification of CD147 (Basigin) as a Mediator of Trophoblast Functions. Hum Reprod (2013) 28:2920-9. doi: 10.1093/humrep/det355

104. Soilleux EJ, Barten R, Trowsdale J. DC-SIGN; a Related Gene, DC-SIGNR; and CD23 Form a Cluster on 19p13. J Immunol (2000) 165:2937-42. doi: 10.4049/jimmunol.165.6.2937

105. Xu MZ, Chan SW, Liu AM, Wong KF, Fan ST, Chen J, et al. AXL Receptor Kinase Is a Mediator of YAP-Dependent Oncogenic Functions in Hepatocellular Carcinoma. Oncogene (2011) 30:8818-52. doi: 10.1038/ onc. 2010.504

106. Shen W-J, Asthana S, Kraemer FB, Azhar S. Thematic Review Series: Lipid Transfer Proteins Scavenger Receptor B Type 1: Expression, Molecular Regulation, and Cholesterol Transport Function. J Lipid Res (2018) 59:1114-31. doi: 10.1194/jlr.R083121

107. Li W, Moore MJ, Vasilieva N, Sui J, Wong SK, Berne MA, et al. AngiotensinConverting Enzyme 2 Is a Functional Receptor for the SARS Coronavirus. Nature (2003) 426:450-4. doi: 10.1038/nature02145

108. Forrester SJ, Booz GW, Sigmund CD, Coffman TM, Kawai T, Rizzo V, et al. Angiotensin II Signal Transduction: An Update on Mechanisms of
Physiology and Pathophysiology. Physiol Rev (2018) 98:1627-738. doi: 10.1152/physrev.00038.2017

109. Gheblawi M, Wang K, Viveiros A, Nguyen Q, Zhong J-C, Turner AJ, et al. Angiotensin-Converting Enzyme 2: SARS-CoV-2 Receptor and Regulator of the Renin-Angiotensin System. Circ Res (2020) 126:1456-74. doi: 10.1161/ CIRCRESAHA.120.317015

110. Bugge TH, Antalis TM, Wu Q. Type II Transmembrane Serine Proteases. J Biol Chem (2009) 284:23177-81. doi: 10.1074/jbc.R109.021006

111. Böttcher-Friebertshäuser E. Membrane-Anchored Serine Proteases: Host Cell Factors in Proteolytic Activation of Viral Glycoproteins. Activation Viruses by Host Proteases (2018) 16:153-203. doi: 10.1007/978-3-319-75474$1 \_8$

112. Matsuyama S, Nagata N, Shirato K, Kawase M, Takeda M, Taguchi F. Efficient Activation of the Severe Acute Respiratory Syndrome Coronavirus Spike Protein by the Transmembrane Protease Tmprss2. J Virol (2010) 84:12658-64. doi: 10.1128/JVI.01542-10

113. Bertram S, Heurich A, Lavender H, Gierer S, Danisch S, Perin P, et al. Influenza and SARS-Coronavirus Activating Proteases TMPRSS2 and HAT Are Expressed at Multiple Sites in Human Respiratory and Gastrointestinal Tracts. PloS One (2012) 7:e35876. doi: 10.1371/ journal.pone.0035876

114. Qian Z, Dominguez SR, Holmes KV. Role of the Spike Glycoprotein of Human Middle East Respiratory Syndrome Coronavirus (MERS-CoV) in Virus Entry and Syncytia Formation. PloS One (2013) 8:e76469. doi: 10.1371/ journal.pone.0076469

115. Shirato K, Kawase M, Matsuyama S. Middle East Respiratory Syndrome Coronavirus Infection Mediated by the Transmembrane Serine Protease Tmprss2. J Virol (2013) 87:12552-61. doi: 10.1128/JVI.01890-13

116. Shulla A, Heald-Sargent T, Subramanya G, Zhao J, Perlman S, Gallagher T. A Transmembrane Serine Protease Is Linked to the Severe Acute Respiratory Syndrome Coronavirus Receptor and Activates Virus Entry. J Virol (2011) 85:873-82. doi: 10.1128/JVI.02062-10

117. Wruck W, Adjaye J. SARS-CoV-2 Receptor ACE2 Is Co-Expressed With Genes Related to Transmembrane Serine Proteases, Viral Entry, Immunity and Cellular Stress. Sci Rep (2020) 10:21415. doi: 10.1038/s41598-02078402-2

118. Matuck BF, Dolhnikoff M, Duarte-Neto AN, Maia G, Gomes SC, Sendyk DI, et al. Salivary Glands Are a Target for SARS-CoV-2: A Source for Saliva Contamination. J Pathol (2021) 254:239-43. doi: 10.1002/path.5679

119. Reyes-Ruiz JM, Osuna-Ramos JF, Bautista-Carbajal P, Jaworski E, SotoAcosta R, Cervantes-Salazar M, et al. Mosquito Cells Persistently Infected With Dengue Virus Produce Viral Particles With Host-Dependent Replication. Virology (2019) 531:1-18. doi: 10.1016/j.virol.2019.02.018

120. Salas Orozco MF, Niño-Martínez N, Martínez-Castañón G-A, Patiño Marín $\mathrm{N}$, Sámano Valencia C, Dipp Velázquez FA, et al. Presence of SARS-CoV-2 and Its Entry Factors in Oral Tissues and Cells: A Systematic Review. Medicina (Kaunas) (2021) 57:523. doi: 10.3390/medicina57060523

121. Huang N, Pérez P, Kato T, Mikami Y, Okuda K, Gilmore RC, et al. SARSCoV-2 Infection of the Oral Cavity and Saliva. Nat Med (2021) 27:892-903. doi: 10.1038/s41591-021-01296-8

122. Koch J, Uckeley ZM, Doldan P, Stanifer M, Boulant S, Lozach P. TMPRSS2 Expression Dictates the Entry Route Used by SARS-CoV-2 to Infect Host Cells. EMBO J (2021) 40:e107821. doi: 10.15252/embj.2021107821

123. Sasaki M, Uemura K, Sato A, Toba S, Sanaki T, Maenaka K, et al. SARS-CoV2 Variants With Mutations at the S1/S2 Cleavage Site Are Generated In Vitro During Propagation in TMPRSS2-Deficient Cells. PloS Pathog (2021) 17: e1009233. doi: 10.1371/journal.ppat.1009233

124. Cagno V, Tseligka ED, Jones ST, Tapparel C. Heparan Sulfate Proteoglycans and Viral Attachment: True Receptors or Adaptation Bias? Viruses (2019) 11:596. doi: 10.3390/v11070596

125. Lang J, Yang N, Deng J, Liu K, Yang P, Zhang G, et al. Inhibition of SARS Pseudovirus Cell Entry by Lactoferrin Binding to Heparan Sulfate Proteoglycans. PloS One (2011) 6:e23710. doi: 10.1371/journal.pone.0023710

126. Milewska A, Zarebski M, Nowak P, Stozek K, Potempa J, Pyrc K. Human Coronavirus NL63 Utilizes Heparan Sulfate Proteoglycans for Attachment to Target Cells. J Virol (2014) 88:13221-30. doi: 10.1128/JVI.02078-14

127. Li W, Hulswit RJG, Widjaja I, Raj VS, McBride R, Peng W, et al. Identification of Sialic Acid-Binding Function for the Middle East 
Respiratory Syndrome Coronavirus Spike Glycoprotein. PNAS (2017) 114: E8508-17. doi: 10.1073/pnas.1712592114

128. Liu L, Chopra P, Li X, Bouwman KM, Tompkins SM, Wolfert MA, et al. Heparan Sulfate Proteoglycans as Attachment Factor for SARS-CoV-2. ACS Cent. Sci (2020) 7:1009-18. doi: 10.1021/acscentsci.1c00010

129. Carey DJ. Syndecans: Multifunctional Cell-Surface Co-Receptors. Biochem J (1997) 327:1-16. doi: 10.1042/bj3270001

130. Teng YH-F, Aquino RS, Park PW. Molecular Functions of Syndecan-1 in Disease. Matrix Biol (2012) 31:3-16. doi: 10.1016/j.matbio.2011.10.001

131. Lin W, Zhang J, Lin H, Li Z, Sun X, Xin D, et al. Syndecan-4 Negatively Regulates Antiviral Signalling by Mediating RIG-I Deubiquitination. via CYLD Nat Commun (2016) 7:11848. doi: 10.1038/ncomms11848

132. Saphire ACS, Bobardt MD, Zhang Z, David G, Gallay PA. Syndecans Serve as Attachment Receptors for Human Immunodeficiency Virus Type 1 on Macrophages. J Virol (2001) 75:9187-200. doi: 10.1128/JVI.75.19.91879200.2001

133. Shafti-Keramat S, Handisurya A, Kriehuber E, Meneguzzi G, Slupetzky K, Kirnbauer R. Different Heparan Sulfate Proteoglycans Serve Ascellular Receptors for HumanPapillomaviruses. J Virol (2003) 77:13125-35. doi: 10.1128/JVI.77.24.13125-13135.2003

134. Tiwari V, O’Donnell C, Copeland RJ, Scarlett T, Liu J, Shukla D. Soluble 3-OSulfated Heparan Sulfate can Trigger Herpes Simplex Virus Type 1 Entry Into Resistant Chinese Hamster Ovary (CHO-K1) Cells. J Gen Virol (2007) 88:1075-9. doi: 10.1099/vir.0.82476-0

135. Shi Q, Jiang J, Luo G. Syndecan-1 Serves as the Major Receptor for Attachment of Hepatitis C Virus to the Surfaces of Hepatocytes. J Virol (2013) 87:6866-75. doi: 10.1128/JVI.03475-12

136. Prieto-Fernández E, Egia-Mendikute L, Vila-Vecilla L, Bosch A, BarreiraManrique A, Lee SY, et al. Hypoxia Reduces Cell Attachment of SARS-CoV2 Spike Protein by Modulating the Expression of ACE2, Neuropilin-1, Syndecan-1 and Cellular Heparan Sulfate. Emerg Microbes Infect (2021) 10:1065-76. doi: 10.1080/22221751.2021.1932607

137. Zimmermann N, Saiga H, Houthuys E, Moura-Alves P, Koehler A, Bandermann S, et al. Syndecans Promote Mycobacterial Internalization by Lung Epithelial Cells. Cell Microbiol (2016) 18:1846-56. doi: 10.1111/ cmi.12627

138. Schaefer I-M, Padera RF, Solomon IH, Kanjilal S, Hammer MM, Hornick JL, et al. In Situ Detection of SARS-CoV-2 in Lungs and Airways of Patients With COVID-19. Mod Pathol (2020) 33:1-11. doi: 10.1038/s41379-020-0595-Z

139. Ketter E, Randall G. Virus Impact on Lipids and Membranes. Annu Rev Virol (2019) 6:319-40. doi: 10.1146/annurev-virology-092818-015748

140. Brandão SCS, Ramos J, de OX, Dompieri LT, Godoi ETAM, Figueiredo JL, et al. Is Toll-Like Receptor 4 Involved in the Severity of COVID-19 Pathology in Patients With Cardiometabolic Comorbidities? Cytokine Growth Factor Rev (2021) 58:102-10. doi: 10.1016/j.cytogfr.2020.09.002

141. Wang H, Yuan Z, Pavel MA, Jablonski SM, Jablonski J, Hobson R, et al. The Role of High Cholesterol in Age-Related COVID19 Lethality. Cell Biol (2020). doi: 10.1101/2020.05.09.086249

142. Yuan Z, Pavel MA, Wang H, Hansen SB. Hydroxychloroquine: Mechanism of Action Inhibiting SARS-CoV2 Entry. Cell Biol (2020). doi: 10.1101/ 2020.08.13.250217

143. Kim J, You Y-J. Regulation of Organelle Function by Metformin: REGULATION OF ORGANELLE FUNCTION BY METFORMIN. IUBMB Life (2017) 69:459-69. doi: 10.1002/iub.1633

144. Liu J, Cao R, Xu M, Wang X, Zhang H, Hu H, et al. Hydroxychloroquine, a Less Toxic Derivative of Chloroquine, Is Effective in Inhibiting SARS-CoV-2 Infection In Vitro. Cell Discovery (2020a) 6:16. doi: 10.1038/s41421-020-0156-0

145. Zhang C-S, Li M, Ma T, Zong Y, Cui J, Feng J-W, et al. Metformin Activates AMPK Through the Lysosomal Pathway. Cell Metab (2016) 24:521-2. doi: 10.1016/j.cmet.2016.09.003

146. Glossmann HH, Lutz OMD. Metformin and Aging: A Review. Gerontology (2019) 65:581-90. doi: 10.1159/000502257

147. Akira S, Takeda K. Toll-Like Receptor Signalling. Nat Rev Immunol (2004) 4:499-511. doi: 10.1038/nri1391

148. Kumar H, Kawai T, Akira S. Toll-Like Receptors and Innate Immunity. Biochem Biophys Res Commun (2009) 388:621-5. doi: 10.1016/j.bbrc. 2009.08.062
149. Kay JG, Murray RZ, Pagan JK, Stow JL. Cytokine Secretion via CholesterolRich Lipid Raft-Associated SNAREs at the Phagocytic Cup * J Biol Chem (2006) 281:11949-54. doi: 10.1074/jbc.M600857200

150. Murray RZ, Stow JL. Cytokine Secretion in Macrophages: SNAREs, Rabs, and Membrane Trafficking. Front Immunol (2014) 5:538. doi: 10.3389/ fimmu.2014.00538

151. Olejnik J, Hume AJ, Mühlberger E. Toll-Like Receptor 4 in Acute Viral Infection: Too Much of a Good Thing. PloS Pathog (2018) 14:e1007390. doi: 10.1371/journal.ppat.1007390

152. Dyavar SR, Singh R, Emani R, Pawar GP, Chaudhari VD, Podany AT, et al. Role of Toll-Like Receptor 7/8 Pathways in Regulation of Interferon Response and Inflammatory Mediators During SARS-CoV2 Infection and Potential Therapeutic Options. BioMed Pharmacother (2021) 141:111794. doi: 10.1016/j.biopha.2021.111794

153. Manik M, Singh RK. Role of Toll-Like Receptors in Modulation of Cytokine Storm Signaling in SARS-CoV-2-Induced COVID-19. J Med Virol (2021) n/ a:1-10. doi: 10.1002/jmv.27405

154. Jeffers SA, Tusell SM, Gillim-Ross L, Hemmila EM, Achenbach JE, Babcock GJ, et al. CD209L (L-SIGN) Is a Receptor for Severe Acute Respiratory Syndrome Coronavirus. Proc Natl Acad Sci USA (2004) 101:15748-53. doi: 10.1073/pnas.0403812101

155. Chan VSF, Chan KYK, Chen Y, Poon LLM, Cheung ANY, Zheng B, et al. Homozygous L-SIGN (CLEC4M) Plays a Protective Role in SARS Coronavirus Infection. Nat Genet (2006) 38:38-46. doi: 10.1038/ng1698

156. Grubaugh ND, Hanage WP, Rasmussen AL. Making Sense of Mutation: What D614G Means for the COVID-19 Pandemic Remains Unclear. Cell (2020) 182:794-5. doi: 10.1016/j.cell.2020.06.040

157. Brufsky A, Lotze MT. Dc/L-SIGNs of Hope in the COVID-19 Pandemic. J Med Virol (2020) 92(9):1396-8. doi: 10.1002/jmv.25980

158. Xie S, Zhang H, Liang Z, Yang X, Cao R. AXL, an Important Host Factor for DENV and ZIKV Replication. Front Cell Infect Microbiol (2021) 11:575346. doi: $10.3389 /$ fcimb.2021.575346

159. Stasi A, Franzin R, Fiorentino M, Squiccimarro E, Castellano G, Gesualdo L. Multifaced Roles of HDL in Sepsis and SARS-CoV-2 Infection: Renal Implications. Int J Mol Sci (2021) 22:5980. doi: 10.3390/ijms22115980

160. Chen Z, Mi L, Xu J, Yu J, Wang X, Jiang J, et al. Function of HAb18G/CD147 in Invasion of Host Cells by Severe Acute Respiratory Syndrome Coronavirus. J Infect Dis (2005) 191:755-60. doi: 10.1086/427811

161. Ahmetaj -B, Vaja R, Atanur SS, George PM, Kirkby NS, Mitchell JA. Cardiorenal Tissues Express SARS-CoV-2 Entry Genes and Basigin (BSG/ CD147) Increases With Age in Endothelial Cells. JACC: Basic to Trans Sci (2020) 5:1111-23. doi: 10.1016/j.jacbts.2020.09.010

162. Su H, Wan C, Wang Z-D, Gao Y, Li Y-C, Tang F, et al. Expression of CD147 and Cyclophilin A in Kidneys of Patients With COVID-19. CJASN (2021) 16:618-9. doi: 10.2215/CJN.09440620

163. Glinka Y, Stoilova S, Mohammed N, Prud'homme GJ. Neuropilin-1 Exerts Co-Receptor Function for TGF-Beta-1 on the Membrane of Cancer Cells and Enhances Responses to Both Latent and Active TGF-Beta. Carcinogenesis (2011) 32:613-21. doi: 10.1093/carcin/bgq281

164. Yan B, Chu H, Yang D, Sze K-H, Lai P-M, Yuan S, et al. Characterization of the Lipidomic Profile of Human Coronavirus-Infected Cells: Implications for Lipid Metabolism Remodeling Upon Coronavirus Replication. Viruses (2019) 11:E73. doi: 10.3390/v11010073

165. Tanner JE, Alfieri C. The Fatty Acid Lipid Metabolism Nexus in COVID-19. Viruses (2021) 13:90. doi: 10.3390/v13010090

166. Thorp EB, Gallagher TM. Requirements for CEACAMs and Cholesterol During Murine Coronavirus Cell Entry. J Virol (2004) 78:2682-92. doi: $10.1128 /$ jvi.78.6.2682-2692.2004

167. Kočar E, Režen T, Rozman D. Cholesterol, Lipoproteins, and COVID-19: Basic Concepts and Clinical Applications. Biochim Biophys Acta Mol Cell Biol Lipids (2021) 1866:158849. doi: 10.1016/j.bbalip.2020.158849

168. Abu-Farha M, Thanaraj TA, Qaddoumi MG, Hashem A, Abubaker J, AlMulla F. The Role of Lipid Metabolism in COVID-19 Virus Infection and as a Drug Target. Int J Mol Sci (2020) 21:3544. doi: 10.3390/ijms21103544

169. Baggen J, Vanstreels E, Jansen S, Daelemans D. Cellular Host Factors for SARS-CoV-2 Infection. Nat Microbiol (2021) 6:1219-32. doi: 10.1038/ s41564-021-00958-0 
170. Schneider WM, Luna JM, Hoffmann H-H, Sánchez-Rivera FJ, Leal AA, Ashbrook AW, et al. Genome-Scale Identification of SARS-CoV-2 and PanCoronavirus Host Factor Networks. Cell (2021) 184:120-132.e14. doi: 10.1016/j.cell.2020.12.006

171. Williams CG, Jureka AS, Silvas JA, Nicolini AM, Chvatal SA, CarlsonStevermer J, et al. Inhibitors of VPS34 and Fatty-Acid Metabolism Suppress SARS-CoV-2 Replication. Cell Rep (2021) 36:109479. doi: 10.1016/ j.celrep.2021.109479

172. Feltes M, Gale SE, Moores S, Ory DS, Schaffer JE. Monitoring the Itinerary of Lysosomal Cholesterol in Niemann-Pick Type C1-Deficient Cells After Cyclodextrin Treatment [S]. J Lipid Res (2020) 61:403-12. doi: 10.1194/ jlr.RA119000571

173. Trimarco JD, Heaton BE, Chaparian RR, Burke KN, Binder RA, Gray GC, et al. TMEM41B Is a Host Factor Required for the Replication of Diverse Coronaviruses Including SARS-CoV-2. PloS Pathog (2021) 17:e1009599. doi: 10.1371/journal.ppat.1009599

174. Dias SSG, Soares VC, Ferreira AC, Sacramento CQ, Fintelman-Rodrigues N, Temerozo JR, et al. Lipid Droplets Fuel SARS-CoV-2 Replication and Production of Inflammatory Mediators. PloS Pathog (2020) 16:e1009127. doi: 10.1371/journal.ppat.1009127

175. Hoffmann H-H, Sánchez-Rivera FJ, Schneider WM, Luna JM, Soto-Feliciano YM, Ashbrook AW, et al. Functional Interrogation of a SARS-CoV-2 Host Protein Interactome Identifies Unique and Shared Coronavirus Host Factors. Cell Host Microbe (2021) 29:267-80.e5. doi: 10.1016/j.chom.2020.12.009

176. Wang R, Simoneau CR, Kulsuptrakul J, Bouhaddou M, Travisano KA, Hayashi JM, et al. Genetic Screens Identify Host Factors for SARS-CoV-2 and Common Cold Coronaviruses. Cell (2021) 184:106-19.e14. doi: 10.1016/ j.cell.2020.12.004

177. Bengoechea-Alonso MT, Ericsson J. SREBP in Signal Transduction: Cholesterol Metabolism and Beyond. Curr Opin Cell Biol (2007) 19:21522. doi: 10.1016/j.ceb.2007.02.004

178. Zhang L-K, Sun Y, Zeng H, Wang Q, Jiang X, Shang W-J, et al. Calcium Channel Blocker Amlodipine Besylate Therapy Is Associated With Reduced Case Fatality Rate of COVID-19 Patients With Hypertension. Cell Discovery (2020) 6:1-12. doi: 10.1038/s41421-020-00235-0

179. Crismaru I, Pantea Stoian A, Bratu OG, Gaman M-A, Stanescu AMA, Bacalbasa N, et al. Low-Density Lipoprotein Cholesterol Lowering Treatment: The Current Approach. Lipids Health Dis (2020) 19:1-10. doi: 10.1186/s12944-020-01275-x

180. Martín-Acebes MA, Vázquez-Calvo Á., Saiz J-C. Lipids and Flaviviruses, Present and Future Perspectives for the Control of Dengue, Zika, and West Nile Viruses. Prog Lipid Res (2016) 64:123-37. doi: 10.1016/ j.plipres.2016.09.005

181. Castiglione V, Chiriacò M, Emdin M, Taddei S, Vergaro G. Statin Therapy in COVID-19 Infection. Eur Heart J Cardiovasc Pharmacother (2020) 6(4):2589. doi: 10.1093/ehjcvp/pvaa042

182. Gorabi AM, Kiaie N, Bianconi V, Jamialahmadi T, Al-Rasadi K, Johnston TP, et al. Antiviral Effects of Statins. Prog Lipid Res (2020) 79:101054. doi: 10.1016/j.plipres.2020.101054

183. Wani MA, Mukherjee S, Mallick S, Akbar I, Basu A. Atorvastatin Ameliorates Viral Burden and Neural Stem/Progenitor Cell (NSPC) Death in an Experimental Model of Japanese Encephalitis. J Biosci (2020) 45:77. doi: 10.1007/s12038-020-00052-3

184. Farfan-Morales CN, Cordero-Rivera CD, Reyes-Ruiz JM, Hurtado-Monzón AM, Osuna-Ramos JF, González-González AM, et al. Anti-Flavivirus Properties of Lipid-Lowering Drugs. Front Physiol (2021) 12:749770. doi: 10.3389 /fphys.2021.749770

185. van Stee MF, de Graaf AA, Groen AK. Actions of Metformin and Statins on Lipid and Glucose Metabolism and Possible Benefit of Combination Therapy. Cardiovasc Diabetol (2018) 17:94. doi: 10.1186/s12933-018-0738-4

186. Orlowski S, Mourad J-J, Gallo A, Bruckert E. Coronaviruses, Cholesterol and Statins: Involvement and Application for Covid-19. Biochimie (2021) 189:51-64. doi: 10.1016/j.biochi.2021.06.005

187. Sorice M, Misasi R, Riitano G, Manganelli V, Martellucci S, Longo A, et al. Targeting Lipid Rafts as a Strategy Against Coronavirus. Front Cell Dev Biol (2021) 8:618296. doi: 10.3389/fcell.2020.618296

188. Zhang X-J, Qin J-J, Cheng X, Shen L, Zhao Y-C, Yuan Y, et al. In-Hospital Use of Statins Is Associated With a Reduced Risk of Mortality Among
Individuals With COVID-19. Cell Metab (2020) 32:176-87.e4. doi: 10.1016/ j.cmet.2020.06.015

189. Torres-Peña JD, Pérez-Belmonte LM, Fuentes-Jiménez F, López Carmona MD, Pérez-Martinez P, López-Miranda J, et al. Prior Treatment With Statins Is Associated With Improved Outcomes of Patients With COVID-19: Data From the SEMI-COVID-19 Registry. Drugs (2021) 81:1-11. doi: 10.1007/ s40265-021-01498-x

190. Fajgenbaum DC, Rader DJ. Teaching Old Drugs New Tricks: Statins for COVID-19? Cell Metabolism (2020) 32:145-7. doi: 10.1016/ j.cmet.2020.07.006

191. Subir R, Jagat J M, Kalyan K,G. Pros and Cons for Use of Statins in People With Coronavirus Disease-19 (COVID-19). Diabetes Metab Syndr (2020) 14:1225-9. doi: 10.1016/j.dsx.2020.07.011

192. Zhao T, Peng L. Letter in Response to the Article: Pros and Cons for Use of Statins in 59 People With Coronavirus Disease-19 (COVID-19) (Ray, S Et al.). Diabetes Metab Syndr (2021) 15:21. doi: 10.1016/j.dsx.2020.11.017

193. Mañes S, del Real G, Lacalle RA, Lucas P, Gómez-Moutón C, SánchezPalomino S, et al. Membrane Raft Microdomains Mediate Lateral Assemblies Required for HIV-1 Infection. EMBO Rep (2000) 1:190-6. doi: 10.1093/ embo-reports/kvd025

194. Liao Z, Graham DR, Hildreth JEK. Lipid Rafts and HIV Pathogenesis: Virion-Associated Cholesterol Is Required for Fusion and Infection of Susceptible Cells. AIDS Res Hum Retroviruses (2003) 19:675-87. doi: 10.1089/088922203322280900

195. del Real G, Jiménez-Baranda S, Mira E, Lacalle RA, Lucas P, Gómez-Moutón C, et al. Statins Inhibit HIV-1 Infection by Down-Regulating Rho Activity. J Exp Med (2004) 200:541-7. doi: 10.1084/jem.20040061

196. Bley H, Schöbel A, Herker E. Whole Lotta Lipids-From HCV RNA Replication to the Mature Viral Particle. Int J Mol Sci (2020) 21:2888. doi: $10.3390 /$ ijms 21082888

197. Fedson DS. Treating Influenza With Statins and Other Immunomodulatory Agents. Antiviral Res (2013) 99:417-35. doi: 10.1016/j.antiviral.2013.06.018

198. Fedson DS, Jacobson JR, Rordam OM, Opal SM. Treating the Host Response to Ebola Virus Disease With Generic Statins and Angiotensin Receptor Blockers. mBio (2015) 6:e00716. doi: 10.1128/mBio.00716-15

199. Ibrahim S, Lowe JR, Bramante CT, Shah S, Klatt NR, Sherwood N, et al. Metformin and Covid-19: Focused Review of Mechanisms and Current Literature Suggesting Benefit. Front Endocrinol (2021) 12:587801. doi: $10.3389 /$ fendo.2021.587801

200. Solymár M, Ivic I, Pótó L, Hegyi P, Garami A, Hartmann P, et al. Metformin Induces Significant Reduction of Body Weight, Total Cholesterol and LDL Levels in the Elderly - A Meta-Analysis. PloS One (2018) 13:1-13. doi: 10.1371/journal.pone.0207947

201. Singh AK, Singh R. Is Metformin Ahead in the Race as a Repurposed HostDirected Therapy for Patients With Diabetes and COVID-19? Diabetes Res Clin Pract (2020) 165:108268. doi: 10.1016/j.diabres.2020.108268

202. Hashemi P, Pezeshki S. Repurposing Metformin for Covid-19 Complications in Patients With Type 2 Diabetes and Insulin Resistance. Immunopharmacol Immunotoxicol (2021) 43:265-70. doi: 10.1080/08923973.2021.1925294

203. O'Carroll SM, O'Neill LAJ. Targeting Immunometabolism to Treat COVID19. Immunother $A d v$ (2021) 1:1-10. doi: 10.1093/immadv/ltab013

204. Luo P, Qiu L, Liu Y, Liu X-L, Zheng J-L, Xue H-Y, et al. Metformin Treatment Was Associated With Decreased Mortality in COVID-19 Patients With Diabetes in a Retrospective Analysis. Am J Trop Med Hyg (2020) 103:69-72. doi: 10.4269/ajtmh.20-0375

205. Ghany R, Palacio A, Dawkins E, Chen G, McCarter D, Forbes E, et al. Metformin Is Associated With Lower Hospitalizations, Mortality and Severe Coronavirus Infection Among Elderly Medicare Minority Patients in 8 States in USA. Diabetes Metab Syndr (2021) 15:513-8. doi: 10.1016/ j.dsx.2021.02.022

206. Lally MA, Tsoukas P, Halladay CW, O’Neill E, Gravenstein S, Rudolph JL. Metformin Is Associated With Decreased 30-Day Mortality Among Nursing Home Residents Infected With SARS-Cov2. J Am Med Dir Assoc (2021) 22:193-8. doi: 10.1016/j.jamda.2020.10.031

207. Cui C, Zhang M, Yao X, Tu S, Hou Z, Jie En VS, et al. Dose Selection of Chloroquine Phosphate for Treatment of COVID-19 Based on a Physiologically Based Pharmacokinetic Model. Acta Pharmaceutica Sinica (2020) 10:1216-27. doi: 10.1016/j.apsb.2020.04.007 
208. Gautret P, Lagier J-C, Parola P, Hoang VT, Meddeb L, Mailhe M, et al. Hydroxychloroquine and Azithromycin as a Treatment of COVID-19: Results of an Open-Label non-Randomized Clinical Trial. Int J Antimicrob Agents (2020) 56:105949. doi: 10.1016/j.ijantimicag.2020.105949

209. Andréjak M, Gras V, Massy ZA, Caron J. [Adverse Effects of Statins]. Therapie (2003) 58:77-83. doi: 10.2515/therapie:2003011

210. Sirtori CR. The Pharmacology of Statins. Pharmacol Res (2014) 88:3-11. doi: 10.1016/j.phrs.2014.03.002

211. DeFronzo R, Fleming GA, Chen K, Bicsak TA. Metformin-Associated Lactic Acidosis: Current Perspectives on Causes and Risk. Metab - Clin Exp (2016) 65:20-9. doi: 10.1016/j.metabol.2015.10.014

212. Bellosta S, Corsini A. Statin Drug Interactions and Related Adverse Reactions: An Update. Expert Opin Drug Saf (2018) 17:25-37. doi: 10.1080/14740338.2018.1394455

213. Maki KC, Diwadkar-Navsariwala V, Kramer MW. Statin Use and Risk for Type 2 Diabetes: What Clinicians Should Know. Postgrad Med (2018) 130:166-72. doi: 10.1080/00325481.2018.1402658

214. Thaker SK, Chapa T, Garcia G, Gong D, Schmid EW, Arumugaswami V, et al. Differential Metabolic Reprogramming by Zika Virus Promotes Cell Death in Human Versus Mosquito Cells. Cell Metab (2019) 29:1206-16.e4. doi: 10.1016/j.cmet.2019.01.024

215. Farfan-Morales CN, Cordero-Rivera CD, Osuna-Ramos JF, Monroy-Muñoz IE, De Jesús-González LA, Muñoz-Medina JE, et al. The Antiviral Effect of Metformin on Zika and Dengue Virus Infection. Sci Rep (2021) 11:8743. doi: 10.1038/s41598-021-87707-9

216. Colson P, Rolain J-M, Lagier J-C, Brouqui P, Raoult D. Chloroquine and Hydroxychloroquine as Available Weapons to Fight COVID-19. Int J Antimicrob Agents (2020) 55:105932. doi: 10.1016/j.ijantimicag.2020.105932
217. Wang T, Du Z, Zhu F, Cao Z, An Y, Gao Y. Comorbidities and Multi-Organ Injuries in the Treatment of COVID-19. The Lancet (2020) 395:e52. doi: 10.1016/S0140-6736(20)30558-4

218. Borba MGS, Val FFA, Sampaio VS, Alexandre MAA, Melo GC, Brito M, et al. Effect of High vs Low Doses of Chloroquine Diphosphate as Adjunctive Therapy for Patients Hospitalized With Severe Acute Respiratory Syndrome Coronavirus 2 (SARS-CoV-2) Infection: A Randomized Clinical Trial. JAMA Netw Open (2020) 3:e208857. doi: 10.1001/jamanetworkopen.2020.8857

Conflict of Interest: The authors declare that the research was conducted in the absence of any commercial or financial relationships that could be construed as a potential conflict of interest.

Publisher's Note: All claims expressed in this article are solely those of the authors and do not necessarily represent those of their affiliated organizations, or those of the publisher, the editors and the reviewers. Any product that may be evaluated in this article, or claim that may be made by its manufacturer, is not guaranteed or endorsed by the publisher.

Copyright (C) 2021 Palacios-Rápalo, De Jesús-González, Cordero-Rivera, Farfan-Morales, Osuna-Ramos, Martínez-Mier, Quistián-Galván, Muñoz-Pérez, Bernal-Dolores, del Ángel and Reyes-Ruiz. This is an open-access article distributed under the terms of the Creative Commons Attribution License (CC BY). The use, distribution or reproduction in other forums is permitted, provided the original author(s) and the copyright owner(s) are credited and that the original publication in this journal is cited, in accordance with accepted academic practice. No use, distribution or reproduction is permitted which does not comply with these terms. 